\title{
NEW ACTINOPTERYGIANS FROM THE PERMIAN OF THE BRIVE BASIN, AND THE ICHTHYOFAUNAS OF THE FRENCH MASSIF CENTRAL
}

\author{
STANISLAV ŠTAMBERG ${ }^{1, *}$, J.-SÉBASTIEN STEYER² \\ ${ }^{1}$ Museum of Eastern Bohemia in Hradec Králové, Eliščino nábřeží 465, 50001 Hradec Králové, the Czech Republic; \\ e-mail: s.stamberg@muzeumhk.cz. \\ ${ }^{2}$ Centre de Recherches en Paléontologie de Paris, UMR7207 CNRS-MNHN-SU-EPHE, Muséum national d'Histoire naturelle CP38, \\ 8 rue Buffon, 75005 Paris, France; e-mail: steyer@mnhn.fr. \\ * corresponding author
}

Stamberg, S., Steyer, J.-S. (2021): New actinopterygians from the Permian of the Brive Basin, and the ichthyofaunas of the French Massif Central. - Fossil Imprint, 77(1): 145-165, Praha. ISSN 2533-4050 (print), ISSN 2533-4069 (on-line).

\begin{abstract}
A new actinopterygian fauna from the Permian of the Brive Basin (Corrèze, Massif Central, France) is described in detail. It is represented by a new pygopterid taxon, Briveichthys chantepieorum gen. et sp. nov., erected and described here on the basis of several well-preserved specimens showing peculiar characters in the bones of the skull roof, parasphenoid, bones of the cheek and opercular apparatus. Other specimens from this new fauna are also described; they are referred to Progyrolepis heyleri PopLIN, 1999, also known in the Bourbon-l'Archambault Basin, and Aeduella cf. blainvillei, which is relatively common in the Permian of France. These discoveries show the importance of the Brive Basin which was previously considered as a rather barren basin in term of palaeontology. This new fauna from Brive is compared with the other Permian ichthyofaunas from France: it is less rich in terms of specimen numbers than the faunas of Bourbon-l'Archambault and Autun, but it is more diversified in terms of number of taxa than the faunas of Lodève and L'Argentière (Ardêche). These actinopterygians, together with other aquatic vertebrates (e.g., acanthodians, sharks etc.), were widespread and diversified in the Hercynian Mountain Chain during the Permian. They indicate that the French basins were connected in time and space. The wide distribution of these aquatic taxa may have been favoured by numerous hydric systems (lakes, rivers etc.) which were well developed under the tropical climate.
\end{abstract}

Key words: Actinopterygii, anatomy, Permian, Brive Basin, French Massif Central

Received: April 27, 2021 | Accepted: July 31, 2021 | Issued: December 9, 2021

Zoobank: http://zoobank.org/urn:Isid:zoobank.org:pub:C7B7D16D-C311-4906-98EA-C5A153982D05

\section{Introduction}

The Permian basins of the Massif Central in France are famous for the rich occurrence of actinopterygians and other vertebrates. A large number of actinopterygians have been described, for instance, from the Autun Basin (e.g., Heyler 1969, Pellenard et al. 2017), Bourbon-l'Archambault (e.g., Heyler 1969, Heyler and Poplin 1990, Poplin 1999, Steyer et al. 2000, Štamberg 2018) and Lodève (e.g., Heyler 1977). The fauna of the Brive Basin has long been neglected: Heyler prospected during two days in 1961 (Heyler 1969: $13,18)$ and briefly mentioned an indeterminate fish bone (Heyler 1969: pl. 20, fig. 11), some acanthodian spines and indeterminate actinopterygian scales (Heyler 2008: 38): these were the only reports of vertebrates in the Permian of Brive so far. Considering this paucity in fossil fish, Heyler (2008: 25) therefore considered the Brive Basin as a "poor basin" in term of palaeontology. However, the amateur palaeontologists Guy and Maryse Chantepie recently collected numerous specimens of actinopterygians from Brive. Their first findings were made in 2007 during construction works for the road (D1089) around the city of Brive-la-Gaillarde (hereafter referred to as "Brive"). Further discoveries have been also made around the village of Lanteuil. These findings form the first comprehensive fossil fish collection from Brive and this article presents the results of the first study of the actinopterygian fauna from the Brive Basin.

\section{Geology}

The Brive Basin is located on the southwestern edge of the Massif Central. The basin is approximately triangular in shape with an area of over $600 \mathrm{~km}^{2}$. Carboniferous and Permian continental sediments infilling the basin have a thickness of 250 to $500 \mathrm{~m}$ in the eastern part of the basin. The Brive Basin extends between the crystalline massif of the Bas-Limousin in the North and the Causses du Quercy in the South (Feys 1989). Most of the Permian sediments are 


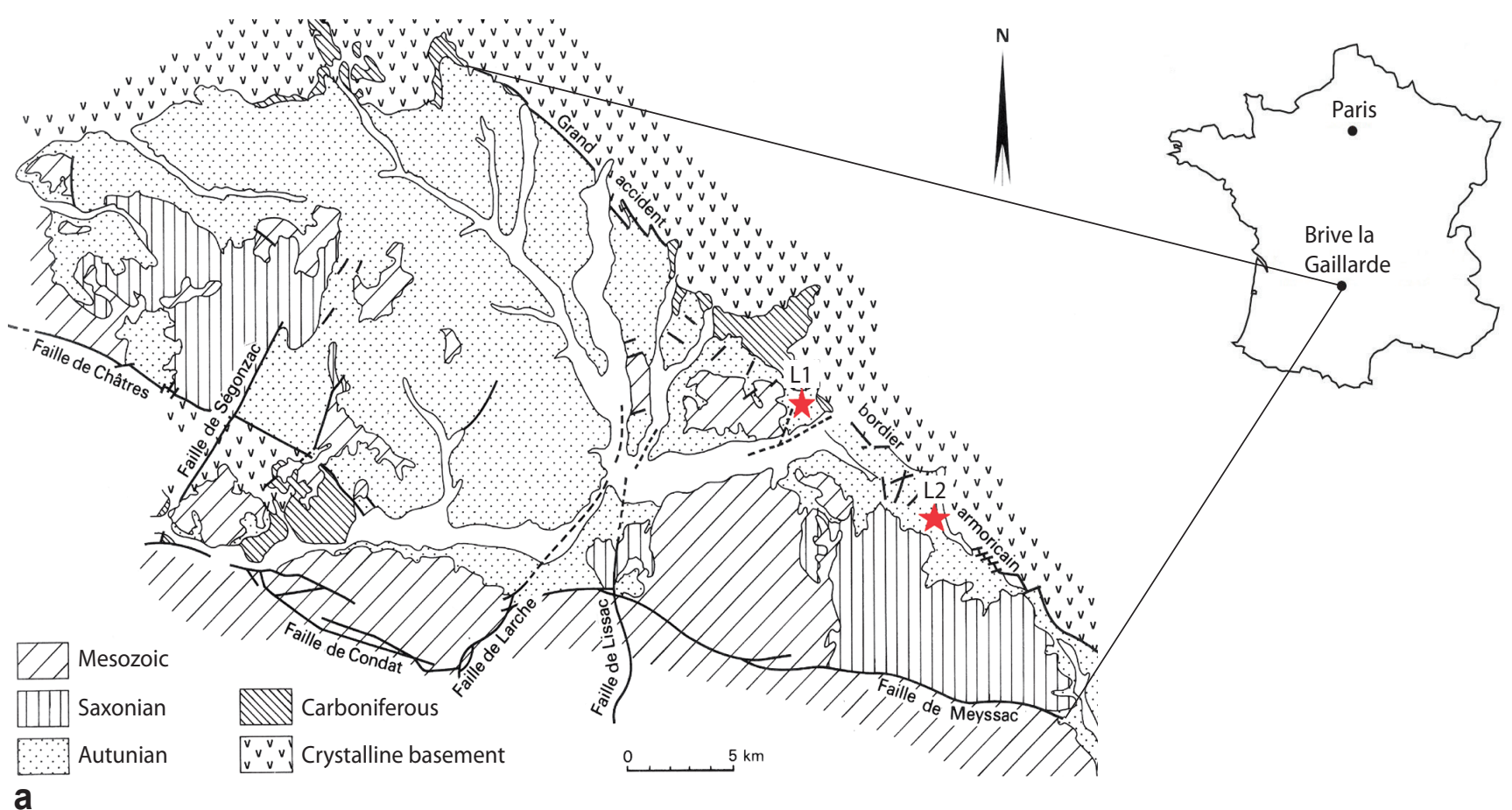

a

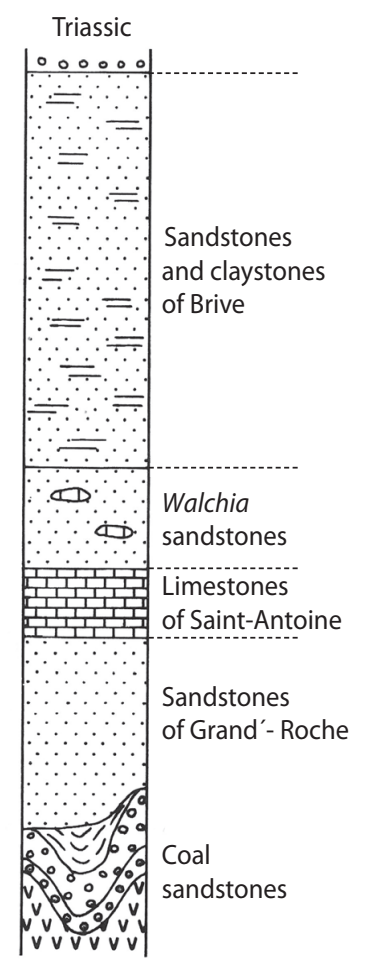

b

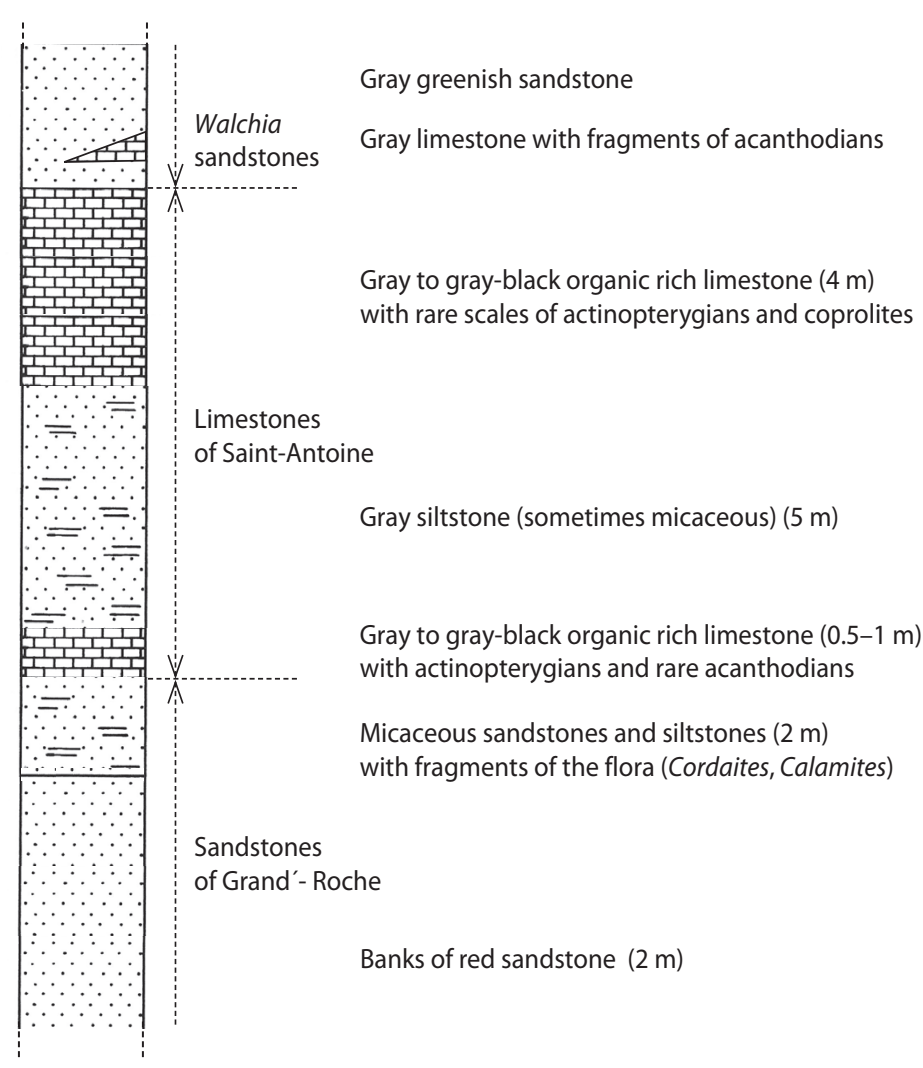

C

Text-fig. 1. a: Simplified geological map of the Permo-Carboniferous Brive Basin (after Feys 1989) with marked localities L 1 (Brive, road D1089), L 2 (Lanteuil). b: Profile of the Brive Basin (modified from Feys 1989). c: Profile recorded by Guy and Maryse Chantepie in 2007 on the type locality Brive, road D1089.

composed of red sandstones, siltstones and conglomerates. The red sandstones yielded very rare plant fossils (Walchia), pelycosaur footprints and indeterminated bioturbations (Guy Chantepie, pers. comm. 2018). Fossil actinopterygians from Brive and Lanteuil are restricted to grey or grey-black lacustrine organic-rich limestones with fine lamination interbedded with siltstones. These sediments were deposited in a quiet lake environment or locally in big ponds or channels. They have high organic matter content, and they represent anoxic offshore sedimentation during a more humid period. In addition to actinopterygians (see below), there are also a high abundance of conchostracan Estheria tenella, together with acanthodian remains of Acanthodes sp., a sphenacanthid tooth and numerous coprolites in the sediments. These sediments may be restricted to the Limestone of Saint-Antoine (Feys 1989; Text-fig. 1) and 
are reminiscent in character and content to the Buxières-lesMines fossiliferous sediments in the Bourbon-l'Archambault Basin (Steyer et al. 2000).

\section{Material and methods}

One hundred and twenty specimens of actinopterygians were collected at the level of the Brive bypass (road D1089) and only five specimens in a private property near Lanteuil (both localities are in the Corrèze Département, France). All specimens were collected by Guy and Maryse Chantepie (GMC) and are deposited in the local Museum of Noailhac (Corrèze Département). The specimen G 123 from the locality Lanteuil is deposited in the collection of the Museum of Eastern Bohemia in Hradec Králové, the Czech Republic.

The material corresponds to body portions, disarticulated skulls and isolated bones. Although often disarticulated, all these elements are very well preserved; they are delineated from the matrix (rendering mechanical preparation possible, see below) and the bones are clearly visible. These actinopterygian specimens are preserved together with scales and spines of acanthodians from the genus Acanthodes. They were mechanically prepared with a Krantz pneumatic needle. Photographs were taken using a Canon EOS 400D camera, and most of the samples were whitened with ammonium chloride for both the photos and drawings. Drawings were prepared using a SM 20 stereomicroscope fitted with a camera lucida. Microsculpture of the scales and teeth were documented using Hitachi S-3700N SEM. The descriptive terminology is derived from Grande and Bemis (1998), Arratia (2008) and Štamberg (2018).

\section{Systematic palaeontology}

\section{Subclass Actinopterygii CoPE, 1877 \\ Family Pygopteridae Aldinger, 1937}

\section{Genus Briveichthys gen. nov.}

Ty pe s pecies. Briveichthys chantepieorum sp. nov.

E ty mology. After Brive and ichthys ('I $\chi \theta 0 ́ \varsigma)$, Greek name for fish.

D i a $\mathrm{g}$ o s is. As for the type species.

\section{Briveichthys chantepieorum gen. et sp. nov.} Text-figs 2-6

Holotype. Specimen GMC 15 with a partially disarticulated skull (Text-figs 2a, 4a-c, e, f, 5d, g), housed in Museum of Noailhac, Noailhac, France.

Paratypes. Specimens GMC 18, GMC 90 and GMC 126.

E ty m o log y. In honour of the collectors Maryse and Guy Chantepie.

Diagnosis. An actinopterygian with predatory dentition, with a very long frontal, three times longer than wide, anteriorly conspicuously concave, and without any large processes on the lateral or medial sides. The medial edge of the frontal is longer than the lateral edge. The parietal is approximately triangular in shape, with pit lines and an ossification centre near the medial edge of the bone. The border between the dermosphenotic and the dermopteroic is anterior to the fronto-parietal border. The dermosphenotic and the nasal form the dorsal and anterior rim of the orbit. The parasphenoid has a large processus ascendens posterior and a small processus ascendens anterior. The maxilla has a large trapezoidal shaped maxillary plate that makes up almost half the length of the maxilla. The maxillary plate extends posteroventrally into a strongly pronounced process which is rounded ventrally. The anterior edge of the maxillary plate is largely covered by the jugal, and it makes an angle of about $45^{\circ}$ with the denticulated lower margin of the maxilla. The maxillary plate bears sculpture composed of pronounced simple ridges that are not vermicularly curved. The teeth form both medial and outer rows. Those teeth on the medial row are large and slender; they are six times higher than those of the outer row which are more numerous and sharply pointed. The antoperculum is of triangular shape and borders $2 / 3$ of the anterior edge of the operculum. The operculum is dorsoventrally elongated and elliptical in shape, slightly narrowing ventrally. Its height is 2.5 times its length. The operculum bears short ridges diverging radially from the ossification centre of the bone. The suboperculum is square shaped and taperes significantly at the front and then exhibits extended anteroventral and anterodorsal corners. The scales bear conspicuous ridges diagonally traversing across their lateral surface to terminate posteriorly in denticulations.

Type locality and horizon. Along the road D1089 at the level of Brive-la-Gaillarde, Corrèze, France. Limestones of Saint-Antoine, lower Permian, Brive Basin, Massif Central, France.

Description. The specimens correspond to adult individuals of approximately $14-18 \mathrm{~cm}$ total length. The largest specimen (GMC 126) is a full adult because it exhibits robust short segments in the lepidotrichia in the pectoral and caudal fins. The shape and position of the fin is not preserved.

Rostral part and skull roof. A fragment of elongated nasal represents the rostral region of the skull on the holotype GMC 15. A fine incision representing the anterior nasal opening is noticeable on the medial edge of the bone. The skull roof is well-preserved in specimen GMC 15 (Textfig. $2 \mathrm{a}, \mathrm{b}$ ) as seen in the frontal, parietal, dermosphenotic and dermopterotic. The frontal is narrow, conspicuously elongated (the length is three times its width). The lateral edges of the right and left frontals are significantly shorter than their medial edges, and without any process. The interfrontal suture is also without process and only slightly wavy. The anterior edge of the frontal is significantly concave in the medial direction. The frontal borders the parietal with a markedly undulating suture. The parietal is triangular in shape, its lateral edge is at least twice the length of the medial edge. The dermosphenotic is also triangular and borders the frontal laterally. Its posterior portion is well preserved on the holotype GMC 15 (Text-fig. 2a, b) but displaced slightly backwards. The dermosphenotic widens posteriorly and tapers anteriorly. It contacts the nasal anteriorly and 

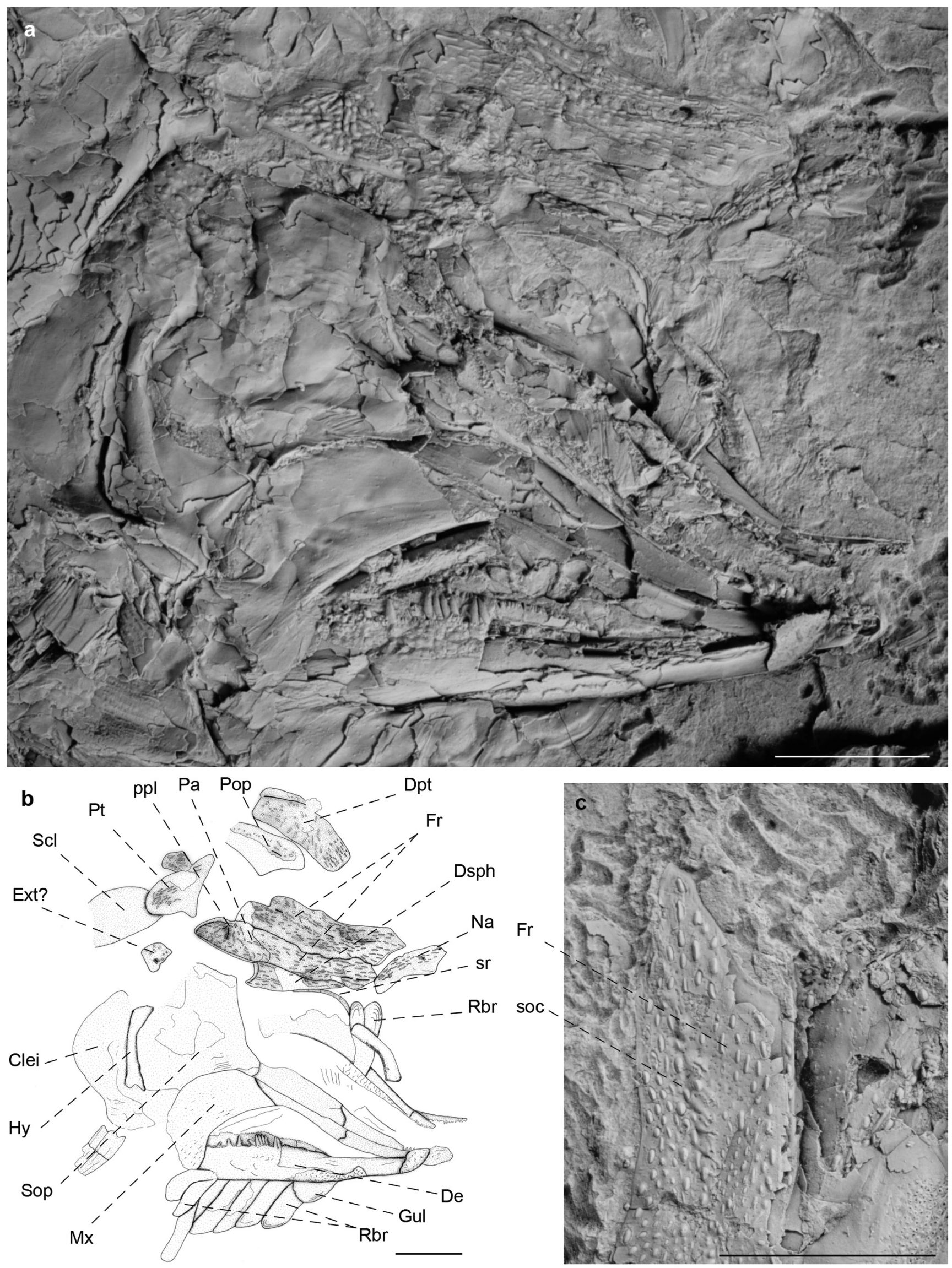

Text-fig. 2. Briveichthys chantepieorum gen. et sp. nov. a, b: whitened photograph and drawing of the skull, GMC 15, scale bars $5 \mathrm{~mm}$; c: anterior part of the left and right frontal in dorsal view, a conspicuous concave anterior edge of the bones is demonstrated, GMC 18, whitened, scale bar 5 mm. Abbreviations: Clei - cleithrum, De - dentalosplenial, Dpt - dermopterotic, Dsph - dermosphenotic, Ext? - extrascapular?, Fr - frontal, Gul - lateral gular, Hy - hyomandibula, Mx - maxilla, Na - nasal, Pa - parietal, Pop - preoperculum, ppl - parietal pit lines, Pt - posttemporal, Rbr - branchiostegal rays, Scl - supracleithrum, soc - supraorbital canal, Sop - suboperculum, sr - sclerotic ring. 
separates the frontal from the orbit. The dermopterotic is well preserved but displaced in GMC 15: it is oblong, anteroposteriorly extended and with conspicuous lateral processes. The border between the dermosphenotic and the dermopterotic is slightly anterior to the border between the parietal and the frontal. The exposed parts of the skull roof bones and the nasal are ornamented with conspicuous short ridges and tubercles. The ridges on the frontal are uniformly arranged in an anteroposterior direction. The supraorbital sensory canal on the left frontal runs parallel to the lateral edge, and appears as a short groove of about a third the width of the bone. The ossification centre of the parietal is close to its median edge and lies at the beginning of its middle and posterior pit lines. The dermopterotic bears the infraorbital sensory canal on its lateral margin. The specimens GMC 18,
GMC 126 and the holotype GMC 15 have narrow frontals with anterior edge conspicuously concave medially (Text-fig. 2c).

The skull roof bones of Briveichthys chantepieorum gen. et sp. nov. differ from those of Progyrolepis heyleri (see Text-fig. 7a, b here, and Štamberg 2018: text-figs 4, 5) in the shape of the frontal which is anteriorly conspicuously concave, the medial edge of the bone is very long while the lateral edge is significantly shorter; the triangular shaped parietal has pit lines and ossification centre located in the medial part of the bone.

Parasphenoid. This bone is preserved in dorsal view in the holotype GMC 15 (Text-fig. 4a, b). It consists of a corpus parasphenoidis, which posteriorly extends into the processus ascendens anterior and the processus ascendens
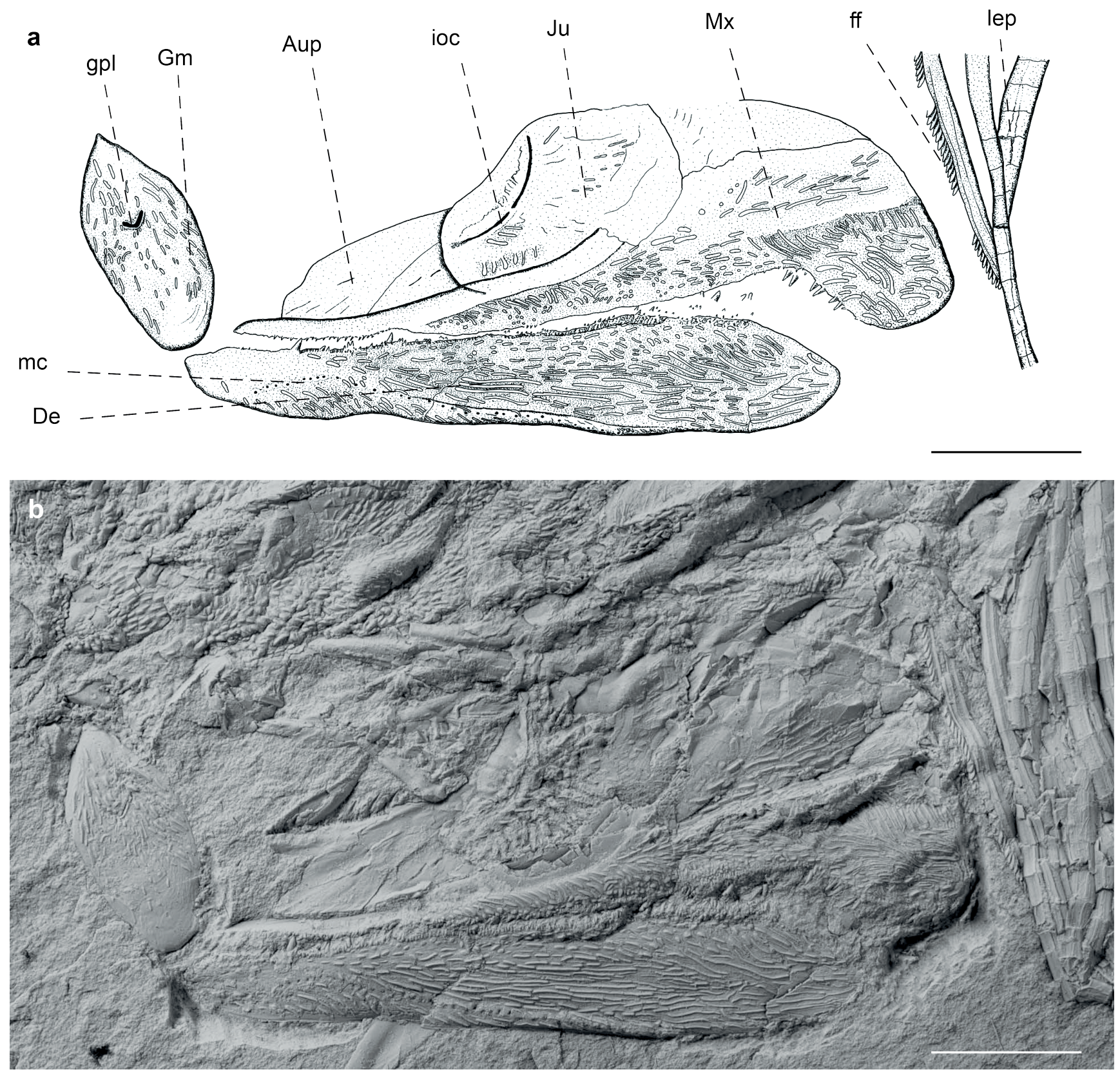

Text-fig. 3. Briveichthys chantepieorum gen. et sp. nov. a, b: drawing and photograph of the jaws, jugal, medial gular and first lepidotrichia of the pectoral fin, GMC 126, whitened, scale bar 5 mm. Abbreviations: Aup - autopalatinum, De - dentalosplenial, ff - fringing fulcra, Gm - medial gular, gpl - gular pit line, ioc - infraorbital sensory canal, Ju - jugal, lep - lepidotrichia, mc - pores of the mandibular sensory canal, Mx - maxilla. 
posterior. The corpus parasphenoidis is elongated and narrows anteriorly. The ossification centre lies in the posterior part of the bone, behind the processus ascendens anterior, at a distance of about one fifth of the full length of the bone from its posterior margin. The posterior region of the corpus parasphenoidis is pierced by the foramen for the bucco-hypophysial canal. The posterior edge of this corpus is slightly convex. Its middle part is convex from its anterior edge to the bucco-hypophysial foramen. The processus ascendens anterior is very small and separated from the processus ascendens posterior. The corpus parasphenoidis widens behind the processus acscendens anterior. It extends in a posterolateral direction into a large processus ascendens posterior, which forms an angle of $75^{\circ}$ with the axis of the corpus parasphenoidis - this angle is $60^{\circ}-68^{\circ}$ in Progyrolepis heyleri which has no processus ascendens anterior. A further difference being that Progyrolepis heyleri has a shortened posterior part of the corpus parasphenoidis.

Cheek. In the holotype GMC 15, the orbit is bordered by the dermosphenotic and the nasal dorsally and anteriorly. A short dorsal and anterior parts of a sclerotical ring are also preserved. The preoperculum is well preserved in medial view (Text-fig. 5c), together with the antoperculum and operculum on GMC 90. The preoperculum is long and consists of two branches, a large anterior branch and a narrow posteroventral branch. The two branches meet forming an angle of $135^{\circ}$. The anterior branch is deep anteriorly, with a concave anterior edge and a slightly pronounced anterodorsal corner. The posteroventral branch has the preopercular sensory canal running along its posterior edge. This canal curves and runs anteriorly along its dorsal edge, and then exits on the dorsal margin in front of the anterior edge of the bone. A portion of the preoperculum is exposed in lateral view on the holotype GMC 15. The deep anterior region of the preoperculum bears a sculpture made of short ridges and tubercles. A large crescent shaped jugal is preserved on GMC 126 (Text-fig. 3), it overlaps the anterior region of the maxillary plate and the dorsal region of the suborbital part of the maxilla. This suborbital part is narrow. The jugal is anteriorly broad and rounded, and dorsally widened. Its anterior concave edge surrounds the orbit. Its partly preserved ornamentation consists of short antero-posterior ridges. A robust hyomandibula is also preserved on GMC 18 and GMC 15 , it is deep and angularly curved. The processus opercularis is formed by the hump of the hyomandibula curve.

Upper jaw. Preserved in specimen GMC 126 is an autopalatinum in the anterior part of the palatoquadratum, and a complete maxilla with a long, low maxillary plate and a narrow suborbital maxillary portion (Text-fig. 3). The length of the maxillary plate is $46 \%$ that of the bone. This maxillary plate is trapezoidal with a ventroposteriorly extended process. This process is rounded ventrally and is larger than that of Progyrolepis heyleri. The anterior edge of the maxillary plate makes an angle of about $45^{\circ}$ with the denticulated ventral margin of the maxilla. The ornamentation on the lateral surface of the bone consists of unbranched ridges. The lateral surface of the dorsal area of the maxillary plate bears sparsely arranged, short and anteroposteriorly directed ridges, whereas the ventral area of the maxillary plate bears densely arranged ridges running in a diagonal direction. A narrow suborbital part of the maxilla bears short ridges diagonally arranged across the bone, and tubercles along the ventral edge of the maxilla. The anterior part of the suborbital part of the maxilla is without any sculpture, and it was probably covered laterally by the lacrymal. The maxilla on GMC 15 exhibits a large maxillary plate with a pronounced posteroventral process and the imprint of the horizontal lamina along the ventral edge of the maxilla (Text-fig. 2a, b).

Lower jaw. The bone is preserved on GMC 18, GMC 126 and the holotype GMC 15. GMC 126 has a robust dentalosplenial with ornamentation on its lateral surface consisting of unbranched diagonally arranged ridges running ventrally to the mandibular canal, and anteroposteriorly arranged ridges running dorsally to the mandibular canal (Text-figs 3, 4d). This ornamentation differs from that of Progyrolepis heyleri which consists exclusively of long ridges regularly arranged in anteroposterior direction (Štamberg 2018: text-fig. 13). The mandibular sensory canal appears as a series of pores along the ventral edge of the bone, and is curved upward in the anterior part of the dentalosplenial. The coronoids are preserved with numerous small teeth along the dorsal edge of the dentalosplenial.

Dentition. The teeth visible on the maxilla and dentalosplenial form two rows, a lateral and a medial row, the lateral teeth are numerous, sharply pointed and very small, whereas the medial ones are slender, less numerous, irregularly spaced and six times higher (Text-fig. 4c, e). The shaft of the tooth bears microsculpture formed by fine protuberances distributed proximo-distally on the surface (Text-fig. 4f). This kind of microsculpture is common in Progyrolepis heyleri (Text-fig. 10h-k; Štamberg 2018: textfig. $15 \mathrm{c}-\mathrm{g}$ ) and other carnivorous actinopterygians (Richter 1983, Schindler 2018). In addition to the marginal teeth, there are small teeth on the coronoids of the lower jaw.

Opercular apparatus. In GMC 90 both the operculum and the antoperculum are preserved (Text-fig. 5a, b). The antoperculum is triangular, deep and firmly attached to the operculum (it borders $2 / 3$ of the anterior edge of the former). The operculum is oval (its maximum length is in its dorsal region), 2.5 times higher than long, and narrows ventrally. Its ossification centre is in a dorsal position, in the anterior sixth of the bone length. The exposed lateral surface of the operculum exhibits concentric lines in its ventral half and diagonal lines in its dorsal half - the latters are short and arranged radially from the ossification centre towards the posterior margin of the operculum. The shape and ornamentation are fundamentally different from those of Progyrolepis heyleri which has an oblong and vermicularly ornamented operculum.

In Briveichthys chantepieorum gen. et sp. nov., the suboperculum is well preserved and several branchiostegal rays and medial and lateral gulars are distinguished among the dermal bones of the opercular apparatus on the holotype GMC 15 (Text-fig. 5g). In lateral view, the suboperculum is square in shape. The bone is deep posteriorly and it enlarges anteriorly, forming two large projections in the anteroventral and anterodorsal corners. The anteroventral projection is pointed, whereas the anterodorsal projection is blunt. On the contrary, the posterodorsal and posteroventral corners of the suboperculum are rounded. This suboperculum is significantly narrowed in its anterior half, which is markedly 

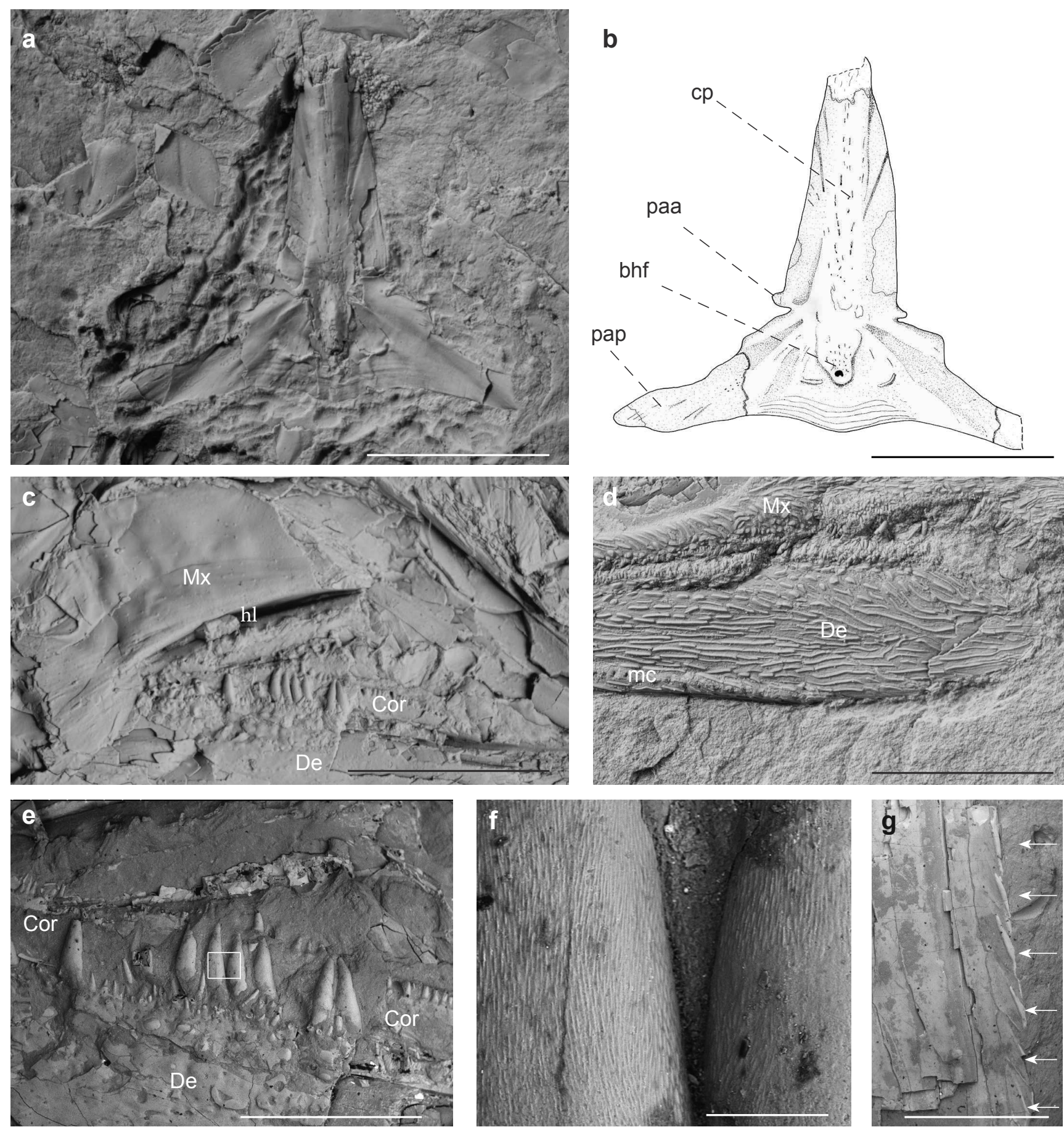

Text-fig. 4. Briveichthys chantepieorum gen. et sp. nov. a, b: photograph and drawing of the parasphenoid in dorsal view, GMC 15, whitened, scale bars $5 \mathrm{~mm}$; c: maxillary plate in medial view with horizontal lamina along the ventral edge of the bone, segment of the lower jaw with assembly of large slender teeth of the inner row and coronoids with small teeth, GMC 15, whitened, scale bar $5 \mathrm{~mm}$; d: detail of the sculpture on the maxilla and dentalosplenial, GMC 126, whitened, scale bar $5 \mathrm{~mm}$; e: detail of the teeth of the inner and outer row and coronoids on the lower jaw, the frame delineates the area illustrated in (f) at higher magnification, GMC 15, scale bar $2 \mathrm{~mm}$; f: microsculpture formed by elliptical proximo-distally elongated protuberances on the large conical teeth, GMC 15, scale bar $100 \mu \mathrm{m}$; g: small fringing fulcra tightly attached to the anterior edge of a lepidotrichium, individual fulcral scales are indicated by arrows, GMC 18, scale bar $2 \mathrm{~mm}$. Abbreviation: bhf - bucco-hypophysial foramen, Cor - coronoids, cp - corpus parasphenoidis, De - dentalosplenial, hl - horizontal lamina, mc - pores of the mandibular sensory canal, Mx - maxilla, paa - processus ascendens anterior, pap - processus ascendens posterior.

different in shape from this bone in Progyrolepis heyleri (Text-fig. 5e, f). In Briveichthys chantepieorum gen. et sp. nov., seven isolated branchiostegal rays are preserved under the lower jaw in GMC 15 (Text-fig. 2a, b), they are elongated, rounded posteriorly and slightly narrowing anteriorly. The total number of branchiostegal rays is estimated to be about
10-12 between the lateral gular and the suboperculum. The lateral gular in front of the branchiostegal rays is conspicuously anteroventrally elongated (Text-fig. 5d). The anterior half of the bone is narrow and it borders medially the medial gular with its concave medial edge. The lateral gular is pointed at the front while its posterior half is enlarged. The 

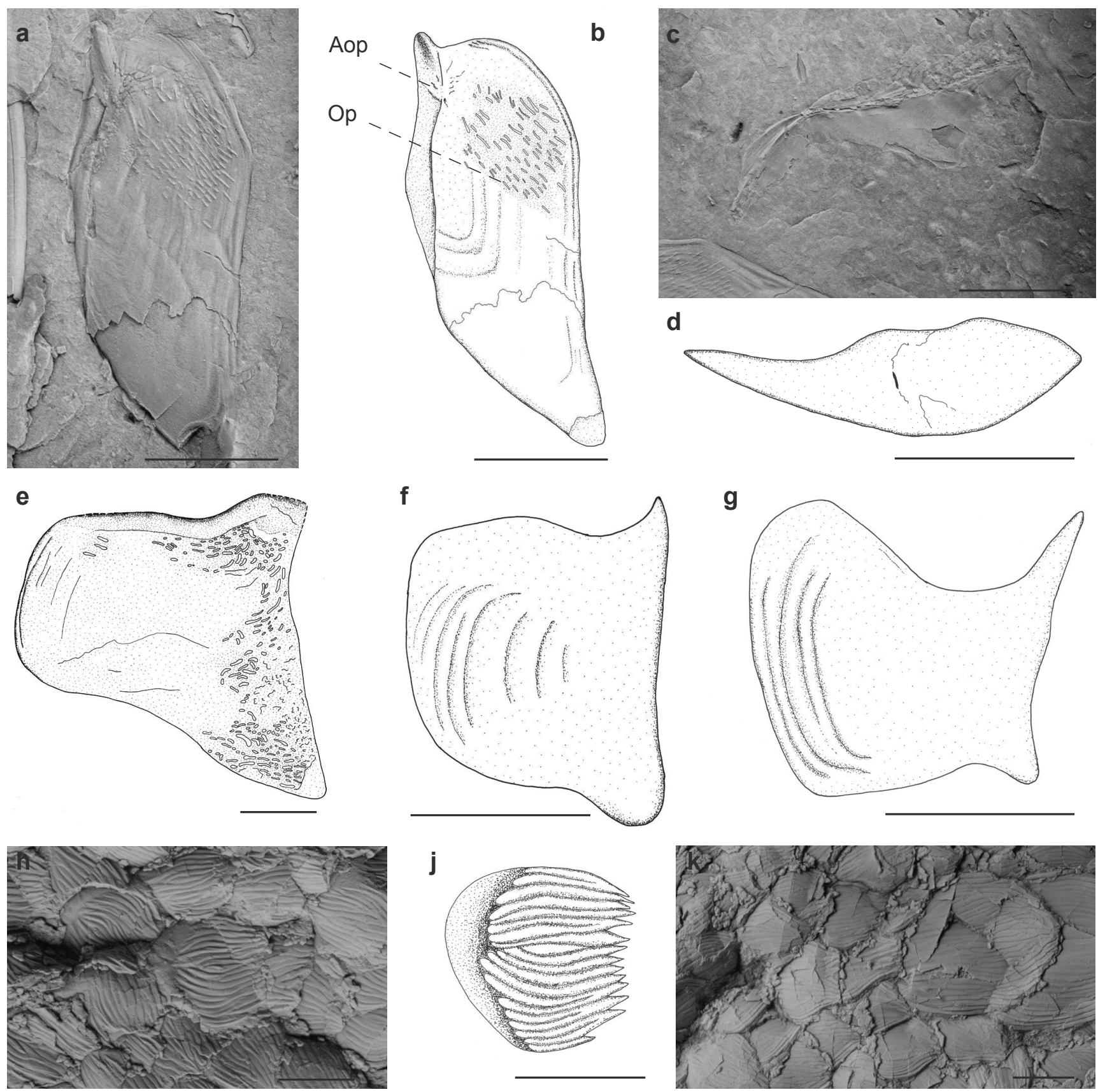

Text-fig. 5. Briveichthys chantepieorum gen. et sp. nov. a, b: photograph and drawing of the left antoperculum and operculum in lateral view, GMC 90, whitened, scale bars $5 \mathrm{~mm}$; c: left preoperculum in medial view, GMC 90, whitened, scale bar 5 mm; d: left lateral gular in dorsal view, GMC 15, scale bar $5 \mathrm{~mm}$; e: drawing of the right suboperculm of Progyrolepis heyleri in lateral view (after Štamberg 2018: text-fig. 19f), scale bar 5 mm; f: left suboperculum of Progyrolepis heyleri in medial view, GMC 116, scale bar 5 mm; g: left suboperculum of Briveichthys chantepieorum gen. et sp. nov. in medial view, GMC 15, scale bar 5 mm; h, j: photograph and drawing of the scale from the midline on the back, GMC 126, whitened, scale bars $2 \mathrm{~mm}$; $\mathrm{k}$ : scales on the back of the body and ridge scale in front of the dorsal fin, GMC 126, whitened, scale bar 2 mm. Abbreviations: Aop - antoperculum, Op - operculum.

pit line in the centre of the bone is visible. The medial gular exposed in ventral view on GMC 126 is oval in shape and relatively large, with its length twice its width (Text-fig. 3). It is pointed at the front, widens posteriorly, and has a rounded posterior edge. The pit line is a V-shape and is located in the anterior half of the bone, at the level of its ossification centre. The ventral surface of the medial gular bears short ridges arranged in an anteroposterior direction. According to the shape of the medial and lateral gulars, two thirds of the posterior part of the medial gular may be laterally bordered by the anterior half of the paired lateral gulars.
Dermal bones of the pectoral girdle. The posttemporal and supracleithrum are well preserved. The posttemporal is exposed in dorsal view on GMC 15, it is oblong, elongated in a mediolateral direction and conspicuously narrower medially. A prominent process on its anterior edge is directed forward. The ornamentation of this bone consists of short ridges arranged in a mediolateral direction. The supracleithrum is dorsoventrally elongated. Its lateral sensory canal runs diagonally across the supracleithrum from the anterodorsal corner of the bone to its mid-postrerior edge. The cleithrum is fragmented and do not provide detailed information about its shape and position. 


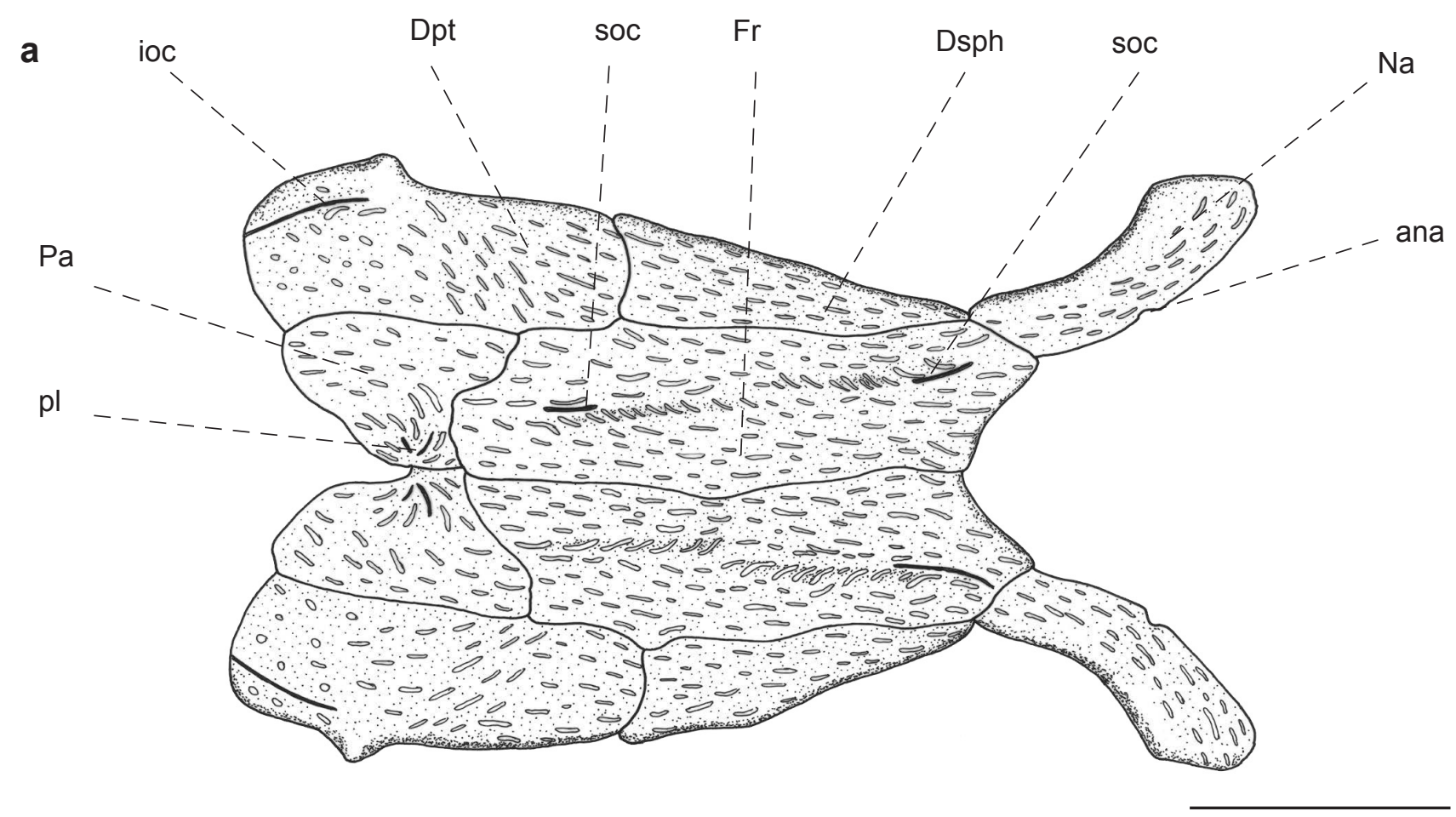

b

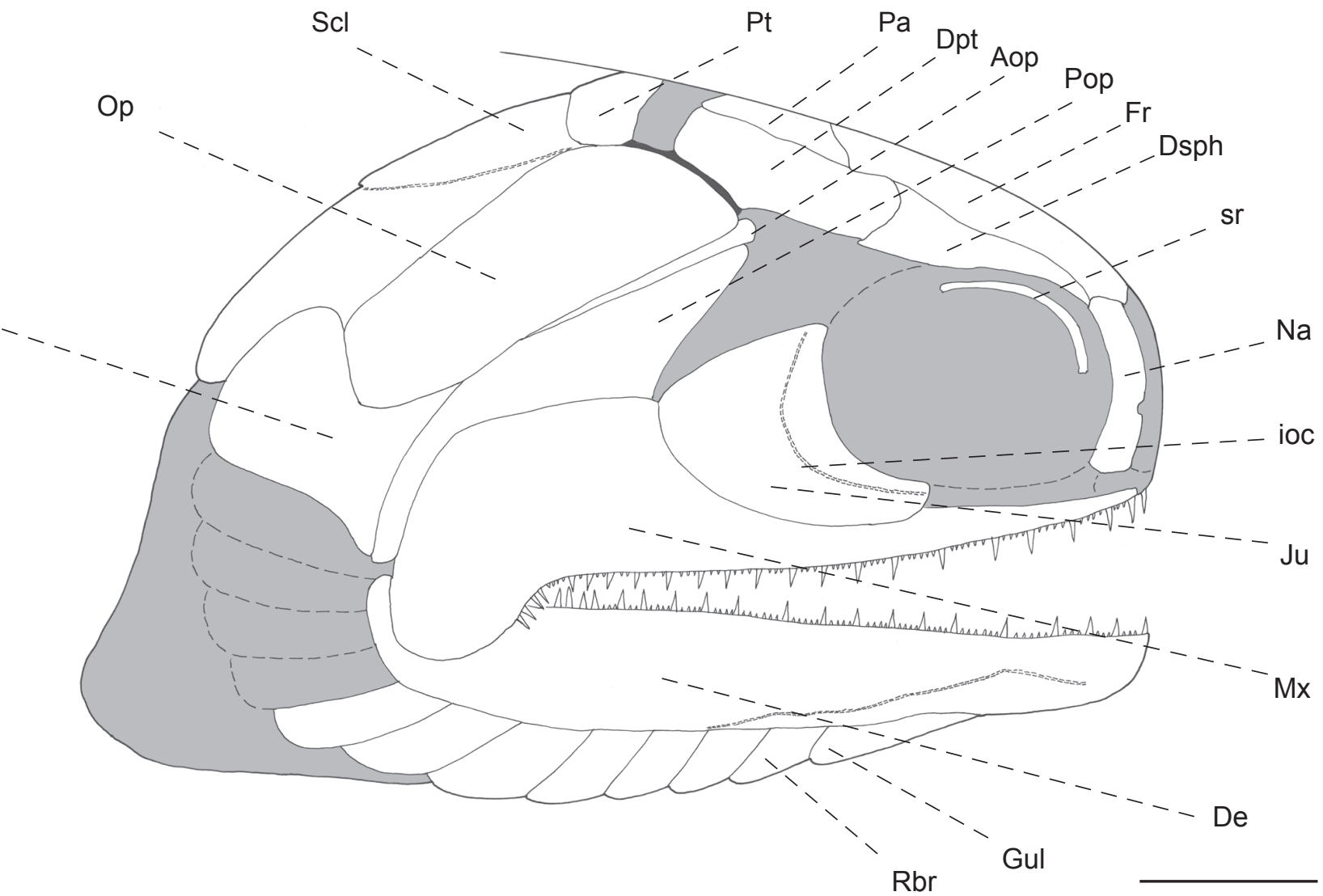

Text-fig. 6. Briveichthys chantepieorum gen. et sp. nov. a: reconstruction of the skull roof and the nasal in dorsal view, scale bar $5 \mathrm{~mm}$; b: reconstruction of the skull in lateral view (parts of the skull which are not clearly retained are in grey colour), scale bar $5 \mathrm{~mm}$. Abbreviations: ana - anterior nasal opening, Aop - antoperculum, De - dentalosplenial, Dpt - dermopterotic, Dsph - dermosphenotic, Fr - frontal, Gul - lateral gular, ioc - infraorbital canal, Ju - jugal, Mx - maxilla, Na - nasal, Op - operculum, Pa - parietal, pl - pit line, Pop - preoperculum, Pt - posttemporal, Rbr - branchiostegal ray, Scl-supracleithrum, soc - supraorbital canal, Sop - suboperculum, $\mathrm{sr}$ - sclerotical ring.

Fins. The pectoral fin and the ventral lobe of the caudal fin are partly preserved. In GMC 18 and GMC 126, the pectoral fin consists of at least 15 robust lepidotrichia. The first lepidotrichium is unsegmented. The entire front edge of the pectoral fin is formed by a single lepidotrichium covered along its whole length by fringing fulcra (Text-figs $3,4 \mathrm{~g}$ ). At least three following lepidotrichia appear segmented beyond the proximal third of their length. The remaining lepidotrichia 
are segmented along their entire length. These segments are short and wide, especially on GMC 126, this suggests an adult growth stage. The ventral lobe of the caudal fin consists of robust lepidotrichia with short wide segments. The anterior edge of the ventral lobe is protected by fringing fulcra together with pointed terminal segments of lepidotrichia.

Scales. The scales are poorly preserved. They have prominent diagonal ridges, which start anteriorly and protrude into the serrations posteriorly. The posterior border of the scales exhibits up to ten serrations. In the ventral part of the body, the long low scales bear only two or three ridges. The peg and socket articulation is well developed. The scales forming the midline on the back are wide. The ridges protruding into the serrations are parallel with the lateral edges of the scale (Text-fig. $5 \mathrm{~h}-\mathrm{j}$ ). In the ventral part of the body, behind the skull, the scales are small in size but robust in shape with short dorsoventral ridges. A large part of the anterior and dorsal regions of the scale are not ornamented and overlap the surrounding scales. Three large ridge scales precede the base of the dorsal fin (Text-fig. 5j).

Comparison. Briveichthys chantepieorum gen. et sp. nov. presents the following unusual characters:

- its parietal is anteriorly separated by a very long frontal medially although the frontal is shorter laterally. The parietal shows medial and posterior pit lines. Its ossification centre is located at the beginning of the medial pit lines, whereas it is located on the lateral side of the bone in other Permo-Carboniferous actinopterygians;

- its dermosphenotic is slender, triangular and contacts anteriorly with the nasal, separating the frontal from the orbit, this is not the case in the Elonichthyidae (sensu Poschman and Schindler 2004);

- its operculum is ellipsoid and shows a different sculpture pattern than that in Progyrolepis heyleri (Text-fig. 9d), Progyrolepis speciosus (FRIČ, 1875) (Štamberg 1991) and Elonichthys germari GieBel, 1848 (Schindler 2018);

- its suboperculum is very shallow anteriorly, with the anterodorsal corner being extremely elongated and prongshaped, and the large anteroventral corner forming a process: this is not the case in other actinopterygians such as Progyrolepis or Letovichthys where both corners are prominent (Stensiö 1921, Aldinger 1937, Štamberg 2007). However, a prong-shaped anterodorsal corner of the suboperculum is also seen in Devonian actinopterygians such as Gogosardinia or Mimipiscis (e.g., Choo 2011) where it is interpreted as a functional replacement for the accessory operculum (Choo et al. 2009). The fact that the suboperculum of Briveichthys is also very shallow anteriorly is a unique character, yet a slight anterior reduction of this bone is also seen in Coccocephalus wildi WATSON, 1925 (Poplin and Véran 1996).

Briveichthys chantepieorum gen. et sp. nov. also shares the following characters with other Permo-Carboniferous actinopterygians:

- it shares the same morphology of the parasphenoid and antoperculum with that of the Pygopteridae;

- its frontal has a concave anterior border as in Coccocephalus wildi (Poplin and Véran 1996), Letovichthys tuberculatus ŠTAMBERG, 2007 and relatives;
- its parietal is subtriangular as in Commentrya traquairi Sauvage, 1888 (Blot 1966), Coccocephalus wildi (Poplin and Véran 1996), Mansfieldiscus sweeti WoOdWARD, 1906 (Long 1988) and Letovichthys tuberculatus (Štamberg 2007);

- its processus ascendens anterior of the parasphenoid is separated at its base from the processus ascendens posterior as in Pygopterus nielseni Aldinger, 1937 (Aldinger 1937: text-fig. 38), Progyrolepis heyleri, Meisenheimichthys palatinus (SCHINDLER, 1993), Elonichthys germari GieBel, 1848 (Schindler 2018) and other Elonichthyidae (sensu Poschmann and Schindler 2004);

- its triangular antoperculum borders two third of the anterior operculum edge as in many species such as Progyrolepis heyleri, Pygopterus nielseni and Howqualepis rostridens LoNG, 1988 (Long 1988). This bone is named the dermohyal in KazancevaSelezneva (1977) who considered its triangular shape as a characteristic of the Pygopteridae. However, it does not fit on the hyomandibular and should be named antoperculum as originally described by Aldinger (1937).

\section{Family Acrolepidae Aldinger, 1937 \\ Genus Progyrolepis Fritsch, 1895}

Type s pe ci es. Gyrolepis speciosus Frič, 1875.

Remark. Genus Progyrolepis belongs to the family Acrolepidae on the basis of its cheek bone pattern, opercular apparatus, shape of the parasphenoid, conical teeth and antoperculum (Štamberg 2018).

In c luded s pecies. Progyrolepis speciosus (Frič, 1875) from the late Pennsylvanian of the Bohemian Massif (the Czech Republic); P. heyleri Poplin, 1999 from the lower Permian of the Bourbon-l'Archambault Basin (France).

\section{Progyrolepis heyleri PoPLIN, 1999}

Text-figs 7-10

D i a g n o s is . See Štamberg (2018).

Material. Forty specimens are described here: GMC 1-11, 22, 25, 29, 38, 41-43, 54-57, 60-62, 74-75, $77,81-84,86,92,97,101,115-116,125,127,130$ and G 123. They correspond to body portions, isolated bones and disarticulated skull bones. They represent juvenile specimens of 50-60 mm of total body length (e.g., GMC 11, GMC 83) and adult specimens with a lower jaw length of 90 mm (e.g., GMC 1, GMC 130, G 123).

Description. Skull roof. The skull roof is clearly visible in GMC 56 which the frontal, parietal, dermopterotic and dermosphenotic bones are preserved (Text-fig. 7a, b). The frontal is very elongated, three times longer than it is wide. Its anterior edge is convex and rounded. Its lateral border has no processes. It makes contact with the dermosphenotic along most of its lateral edge and slightly with the dermopterotic in its posterior region. The interfrontal suture forms a significant process. Traces of the supraorbital canal are visible on both frontals. The supraorbital canal runs along the frontal, from its anterior border posteriorly to its lateral 

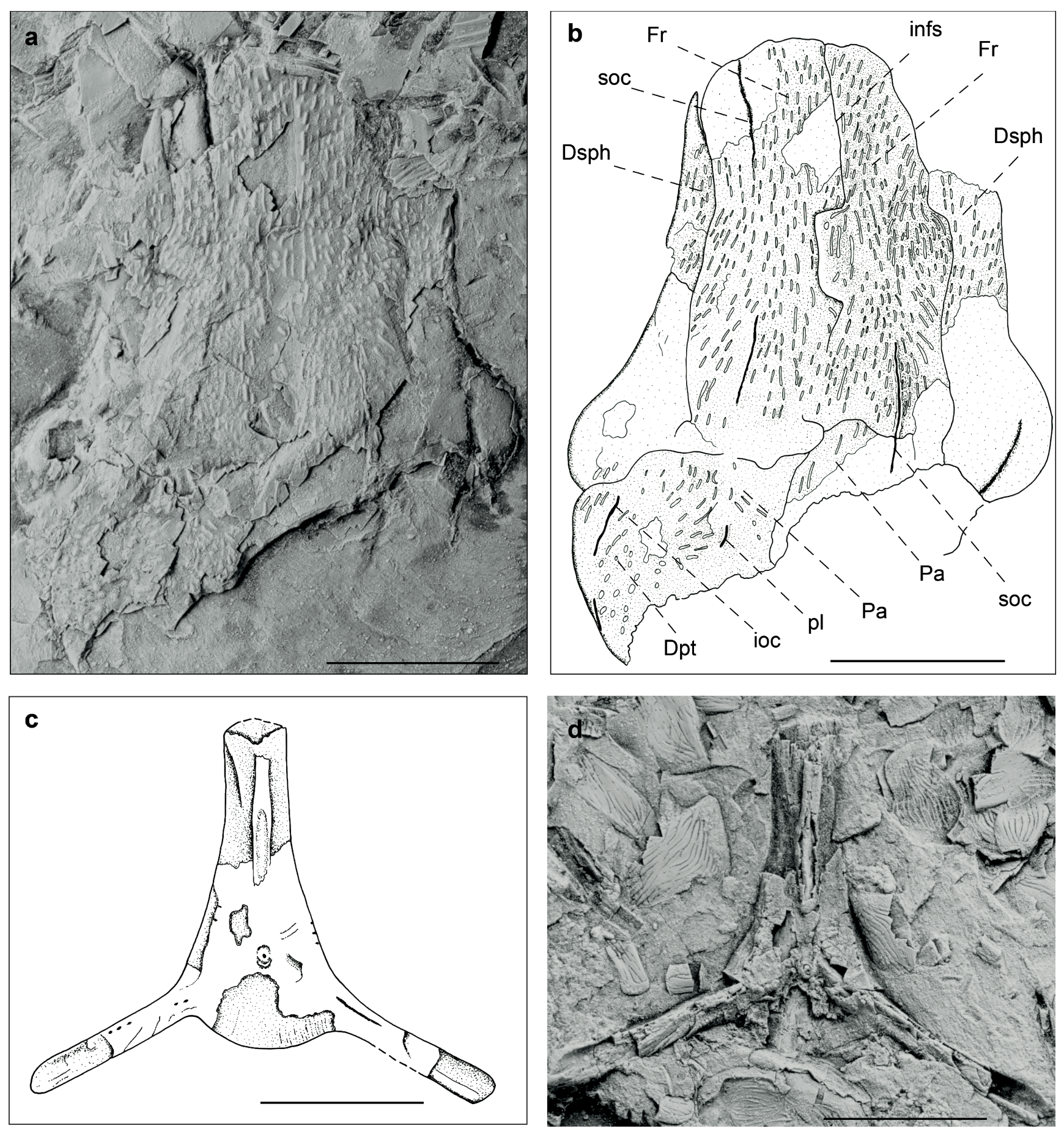

Text-fig. 7. Progyrolepis heyleri Poplin, 1999. a, b: whitened photograph and drawing of the skull roof in dorsal view, GMC 56, scale bars $5 \mathrm{~mm}$; c, d: drawing and whitened photograph of the parasphenoid in dorsal view, GMC 84, scale bars 5 mm. Abbreviations: Dsph - dermosphenotic, Dpt - dermopterotic, Fr - frontal, infs - interfrontal suture, ioc - infraorbital sensory canal, Pa - parietal, pl - parietal pit line, soc - supraorbital sensory canal.

edge. It does not run close to the lateral edge of the frontal, as in many Palaeozoic actinopterygians, but extends to about one-third of the width of the bone from its lateral edge (Text-fig. 7a, b). The sculpture on the exposed surface of the frontal is very conspicuous, and consists of very short ridges anteroposteriorly oriented. The ossification centre of the bone lies at equal distance between its anterior and posterior borders where the supraorbital canal runs. The shape of the parietal cannot be determinate accurately because its contact with the dermopterotic is covered by ornamentation, and its posterior region is missing. The supraorbital canal runs from the frontal to the parietal on which its anterior pit line is preserved. The sculpture on the parietal is similar to that of the frontal. The dermosphenotic is narrow and triangular; pointing anteriorly and slightly widening posteriorly. It borders the frontal laterally and the dermopterotic posteriorly. The dermosphenotic-dermopterotic borderline is displaced posteriorly but it is slightly anterior to, and aligned with, the fronto-parietal borderline. The dermopterotic is slightly elongated with traces of the infraorbital canal laterally.

An isolated right frontal is visible in dorsal view on GMC 81 (Text-fig. 9d), it is twice longer than wide but widens 

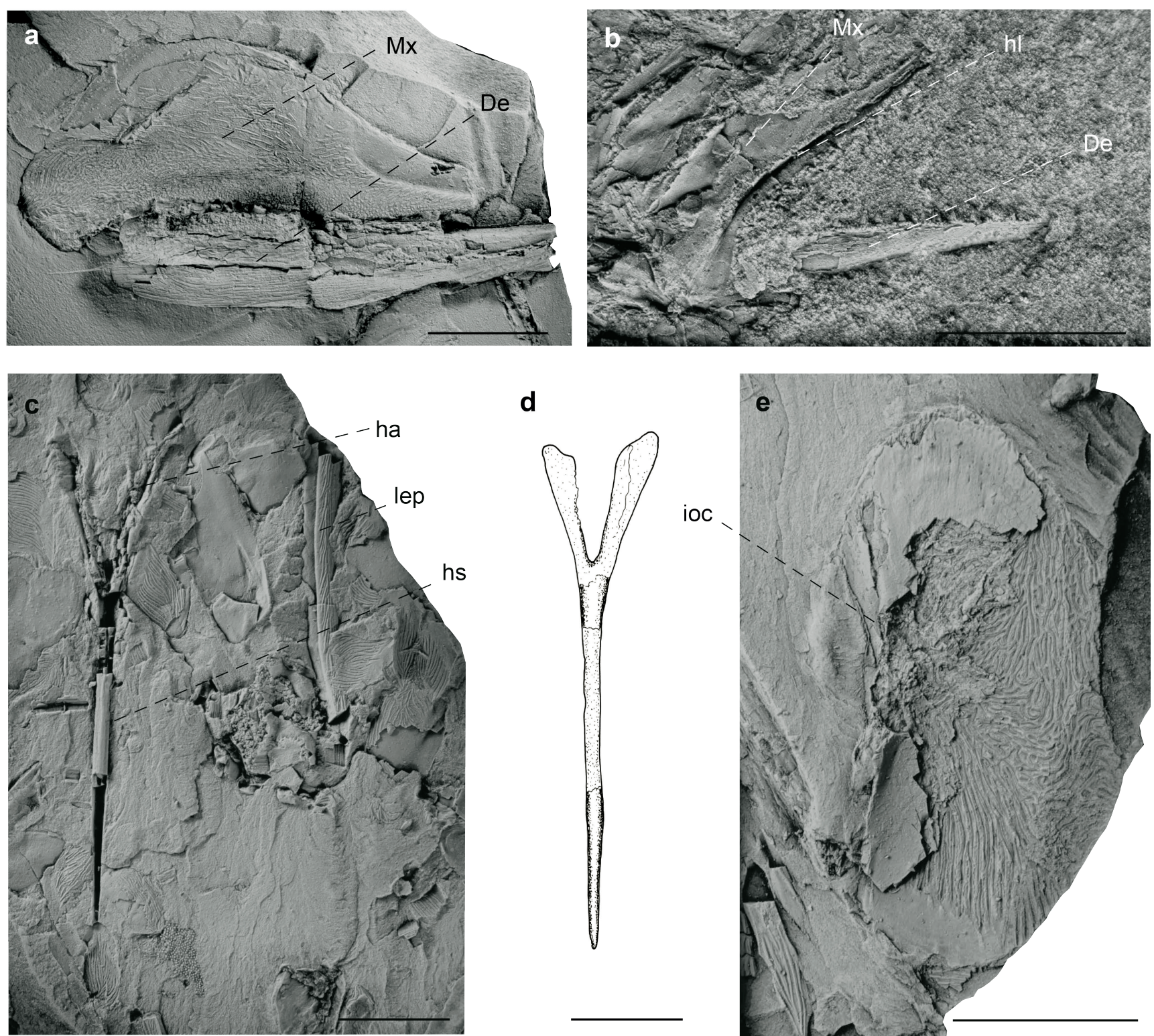

d
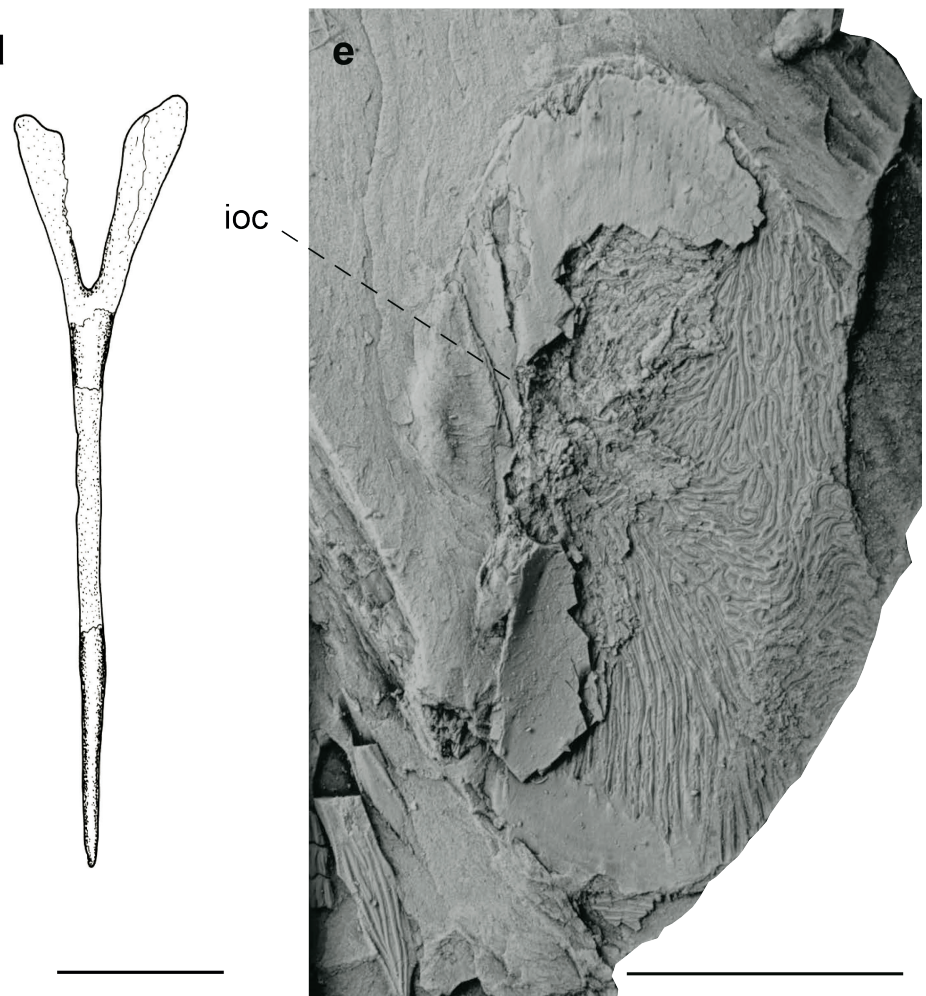

Text-fig. 8. Progyrolepis heyleri PopLIN, 1999. a: maxilla and lower jaw of juvenile specimen in lateral view, GMC 43, whitened, scale bar $5 \mathrm{~mm}$; b: maxilla and lower jaw of juvenile specimen, imprint of the maxillary medial face with a distinctive horizontal lamina, lower jaw in lateral view, GMC 83, whitened, scale bar $5 \mathrm{~mm}$; c: haemal arch of the axial skeleton and fragment of a strong undivided lepidotrichium, GMC 25, whitened, scale bar $5 \mathrm{~mm}$; d: drawing of the haemal arch, GMC 25, scale bar 5 mm; e: jugal in medial view with the infraorbital sensory canal and imprint of the sculpture on the lateral face of the bone, GMC 7, whitened, scale bar 5 mm. Abbreviations: ha - haemal arch, hl - horizontal lamina, hs - haemal spine, ioc - infraorbital sensory canal, lep - lepidotrichium.

posteriorly. Its medial edge forms a smooth narrow strip on which the left frontal was overlapping. The interfrontal suture forms a small but conspicuous process which maintained both right and left frontals. The dorsal sculpture of the frontal consists of conspicuous short ridges posteriorly and tubercles anteriorly. The intersection of the ridges and tubercles marks the region of the radiation centre where the supraorbital sensory canal runs at the level of the interfrontal suture process. The supraorbital canal is not well preserved on the dorsal surface of the frontal but its posterior opening is visible at the level of a posterior notch of the bone.

The shape of the frontal, a curved interfrontal suture forming a large process, ornamentation composed of short anteroposterior ridges, and a dermopterotic-dermosphenotic borderline not extending beyond the frontal-parietal borderline are typical characters of Progyrolepis heyleri, also known from the Permian of Buxières-les-Mines (Štamberg 2018).

Parasphenoid. The bone is visible in dorsal view on GMC 84 (Text-fig. 7c, d), the corpus parasphenoidis stretches anteroposteriorly. It narrows anteriorly and terminates semicircularly posteriorly. Its ossification centre is located at the level of the bucco-hypophysial foramen, in the posterior third of the corpus parasphenoidis. A significant convex medial part extends from this ossification centre to the anterior edge of the bone, and along its medial part, passes grooves where the parabasal canal continues. The paired processus ascendens posterior extend laterally in the posterior third of the corpus parasphenoidis, at an angle of $60^{\circ}$. This angle of $60^{\circ}$, together with the shape of the parasphenoid, is similar to the angle of $68^{\circ}$ detected in Progyrolepis heyleri from Buxières-les-Mines (Štamberg 2018). 

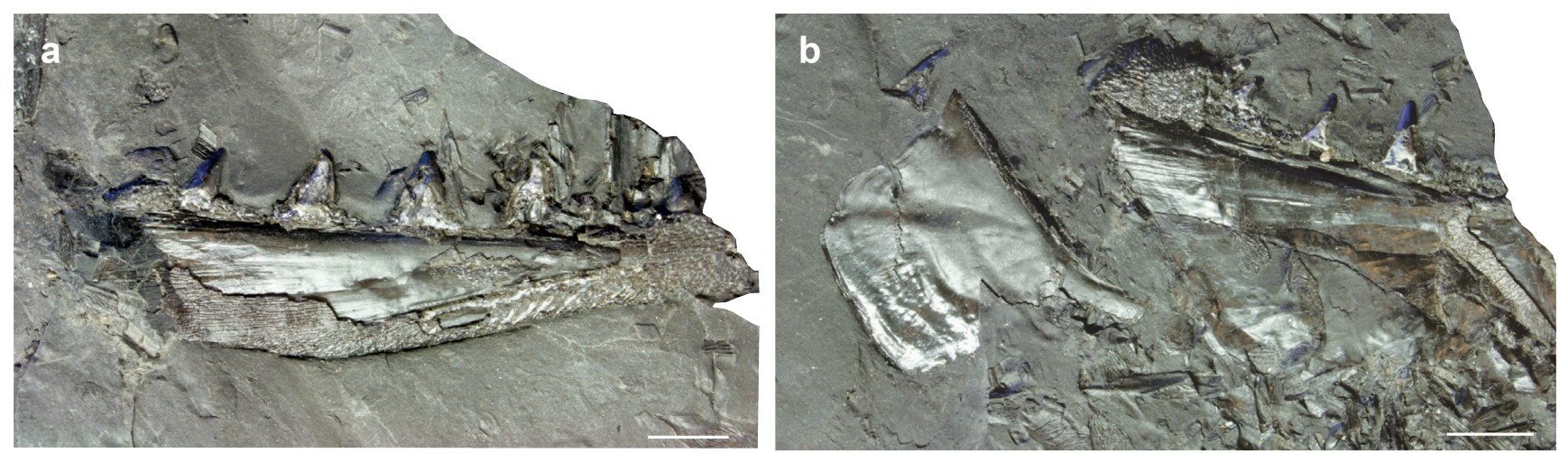

C

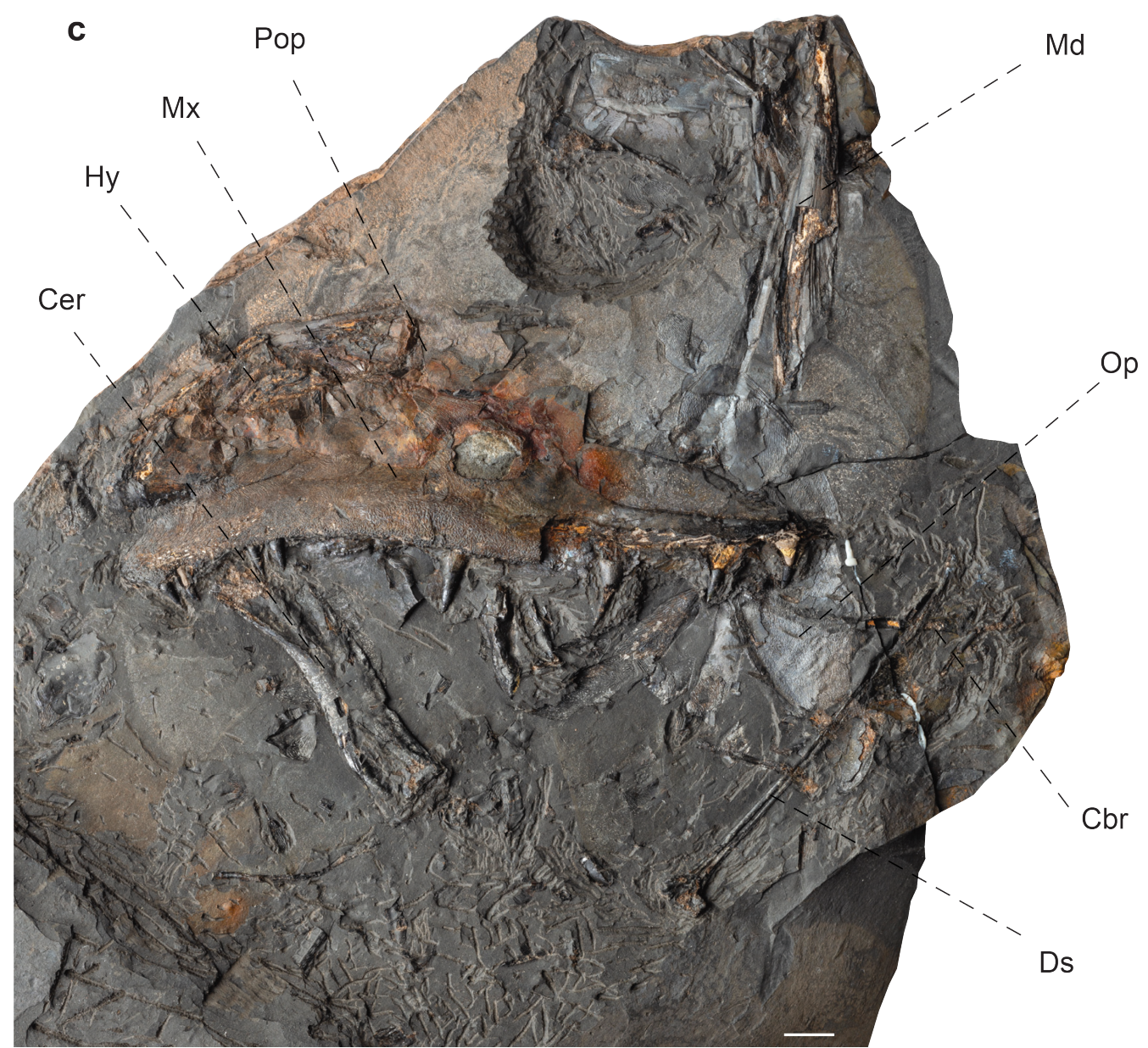

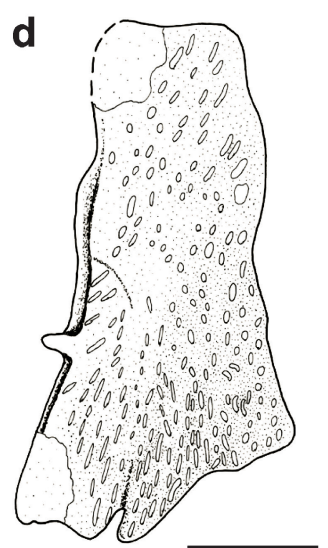

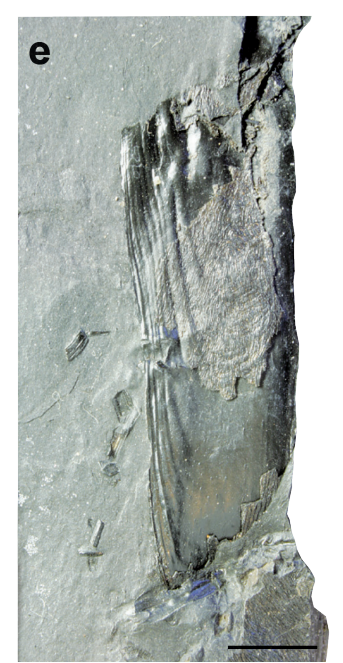

Text-fig. 9. Progyrolepis heyleri PopLin, 1999. a: right dentalosplenial of adult specimen in lateral view, GMC 1, scale bar 5 mm; b: left dentalospelenial and suboperculum in medial view, GMC 1, scale bar $5 \mathrm{~mm}$; c: set of bones of the right side of the cheek displaying maxilla, preoperculum, hyomandibula, left and right ceratohyal, epibranchial and neural spine from the axial skeleton, G 123, scale bar 5 mm; d: drawing of the right frontal in dorsal view, GMC 81, scale bar 5 mm; e: right operculum in lateral view, GMC 10, scale bar 5 mm. Abbreviations: Cbr - ceratobranchial, Cer - ceratohyal, Ds - dorsal spine, Hy - hyomandibula, Md - mandible, Mx - maxilla, Op - operculum, Pop - preoperculum.

Preoperculum. It is partly preserved on G 123 where it appears as an elongated bone, bent along the posterior and dorsal borders of the maxilla (Text-fig. 9c). Dorsally, its posterior region is smooth and narrow whereas its anterior region is widened and ornamented by elongated ridges. Its anterior branch is deep and concave anteriorly. Its anterodorsal corner is more pronounced anteriorly than its anteroventral corner.

Maxilla. This bone can be observed on both juvenile (e.g., GMC 60, GMC 83; Text-fig. 8b) and adult (e.g., G 123; Text-fig. 9c) specimens and has a length from 60 to $80 \mathrm{~mm}$.
It consists of a narrow anterior suborbital region and a long deep maxillary plate. In juvenile and larger specimens (e.g., GMC 43; Text-fig. 8a), the length of the maxillary plate is about half that of the bone and its height twice that of the bone. This maxillary plate extends posteroventrally as a strong process. In GMC 83, the maxilla is visible in medial view with a distinct horizontal lamina forming a ventral maxillary edge (Text-fig. 8b). This horizontal lamina extends from the anterior extremity of the maxilla to one third of the maxillary plate length. The maxillary plate of the adult specimen G 123 exhibits ornamentation composed 
of numerous tubercles along posterior margin of the plate. These long ridges turn into vermicular ridges towards the centre of the maxillary plate. Dorsally, the maxillary plate also bears long ridges arranged anteroposteriorly. The apices of the tubercles and ridges bear microsculpture consisting of ridges similar to those in Progyrolepis heyleri (Poplin 1999, Stamberg 2018). The sculpture is missing on the dorsal part of the anterior suborbital region of the bone and on the anterior part of the maxillary plate because they were overlapped by the large jugal and the narrow lacrymal. The angle between the anterior margin of the maxillary plate and the denticulate ventral margin of the maxilla is about $35^{\circ}$ in the juvenile specimens GMC 43 and GMC 75. It is extrapolated to between $45^{\circ}$ and $50^{\circ}$ in the adult specimen G 123 where the anterior margin of the maxillary is not well preserved.

Lower jaw. This is a robust element of the skull. The dentalosplenial is preserved in the juvenile specimens GMC 43 and GMC 83 (Text-fig. 8a, b) and in the adults GMC 1 (Textfig. 9a, b) and GMC 130 together with a poorly preserved pars articularis posteriorly. In juveniles, the exposed lateral surface of the dentalosplenial bears sculpture composed of long ridges parallel to the ventral edge of the bone. In adults, short ridges and tubercles are visible along the ventral edge and anterior region of the bone, whereas its posterior region bears long ridges running parallel to the ventral edge.

Dentition. On both the dentalosplenial and maxilla, the teeth are arranged in two rows; the outer row consisting of numerous small and sharply pointed teeth and the inner row of large conical teeth. The juvenile GMC 83 has 12-14 large conical teeth in its inner row. These large conical teeth are thinner than those of the adults and are sometimes (e.g., GMC 42) not regularly spaced. On the maxilla of the adult G 123 (Text-fig. 9c), the large conical teeth are 3.8-7.5 mm high and $1.9-3.2 \mathrm{~mm}$ wide (= height/width ratio of $2-2.3$ ). The highest teeth are in the anterior region of the maxilla, their height then decreases posteriorly and the shortest ones are on the ventral edge of the maxillary plate. The maxilla carries large conical teeth along the ventral edge of the posterior region of the maxillary plate. On the lower jaw, the inner row is composed of the same large conical teeth which are regularly spaced (Text-fig. 9a, b). This dentition is consistent with that of Progyrolepis heyleri from the Bourbon-l'Archambault Basin (Poplin 1999, Štamberg 2018). Similarly the microsculpture formed by fine protuberances of elliptical shape (Text-fig. 10i, k) covering the whole surface of the tooth, in addition to the acrodin apex, is the same as in Progyrolepis heyleri described by Stamberg (2018: text-fig. 15d, e, g) and in Briveichthys chantepieorum gen. et sp. nov. The elliptical protuberances are proximo-distally elongated, they have an outer sharp edge, and it is assumed that these fine edges facilitated the penetration of the tooth into the meat tissue.

Jugal. It is preserved in medial view on GMC 7 where it is oval, slightly elongated dorsoventrally, and it forms the posterior edge of the orbit (Text-fig. 8e). It covered the anterior part of the maxillary plate during the animal's lifetime. The infraorbital canal has an arcuate shape on the anterior half of the bone. On the lateral surface of the jugal its ornamented negative imprint is exposed. Ventrally, the ornamentation consists of a long ridge parallel to the ventral branch of the infraorbital canal. Posteriorly and dorsally, it consists of short ridges vermicularly arranged. This large jugal is similar to that of Progyrolepis heyleri from Bourbon-l'Archambault (Štamberg 2018), Elonichthys germari (Schindler 2018), E. krejcii (FRITSCH, 1895) (Štamberg 2010), Moythomasia durgaringa (Gardiner 1984) or Mansfieldiscus sweeti (Long 1988).

Hyoid arch. The hyomandibula and the ceratohyal are visible in G 123. The hyomandibula is a large, stout bone which consists of two clearly distinct arms forming an angle of $150^{\circ}$ (Text-fig. 9c). The anterodorsal arm is widest anteriorly. In lateral view, the well-developed processus opercularis, visible at the level of the maximum curvature of the bone, faces backwards. In medial view, the right ceratohyal is robust, slightly curved and mediolaterally compressed (Text-fig. 9c). The shape of the bone is exactly the same as in Progyrolepis heyleri (Štamberg 2018: textfig. 16e, f).

Branchial arch. Long and thin branchial bones are preserved in GMC 75, G 123 and other specimens, but not in their original positions. The ceratobranchials are recognizable by their slightly widened extremities (Textfig. 9c).

Operculum. It is preserved in G 123, GMC 9, GMC 10, GMC 11, GMC 75. It is rectangular, with rounded corners and very deep (about three times deeper than long). Its anterodorsal corner slightly protrudes anteriorly. Its outer surface is sculptured by closely arranged vermicular ridges (Text-fig. 9e). The suboperculum, sub-square in shape, is preserved in GMC 1 and GMC 116. Its anteroventral and anterodorsal corners protrude, the latter terminating as a pointed projection (Text-figs 5f, 9b). The ossification centre lies in the ventral third of the bone, near its anterior border. Several branchiostegal rays are preserved in a number of specimens but their original location cannot be determinated.

The shape and vermicular sculpture of the operculum and suboperculum are identical to those of Progyrolepis heyleri. This operculum differs significantly from that of Progyrolepis speciosus (Štamberg 1991) and of Briveichthys chantepieorum gen. et sp. nov. by its sculpture. However, the suboperculum shows significantly protruding anterodorsal and anteroventral corners in both Progyrolepis heyleri and Progyrolepis speciosus (Štamberg 1991, 2018).

Dermal bones of the pectoral girdle. The posttemporal, preserved in dorsal view on GMC 74, is isolated: it is oval and wide. It shows a prominent process at about the middle of its anterior edge. It is ornamented, and the ornamentation consists of conspicuous ridges vermicularly arranged on most of its dorsal surface, and short ridges and tubercles in its medial region. The anterior margin of the posttemporal, including the process, is smooth and was probably overlapped by extrascapular bones.

The supracleithrum (GMC 38, GMC 115) is very high, with a large process on its dorsal edge. This bone narrows ventrally. Its posterior edge is slightly concave. It is ornamented on its lateral surface and partly on its ventral surface by prominent long ridges arranged in a dorsoventral direction. The lateral sensory canal traverses diagonally across the dorsal third of the bone and traverses from the supracleithrum to the scales one third of the way down its posterior margin. 

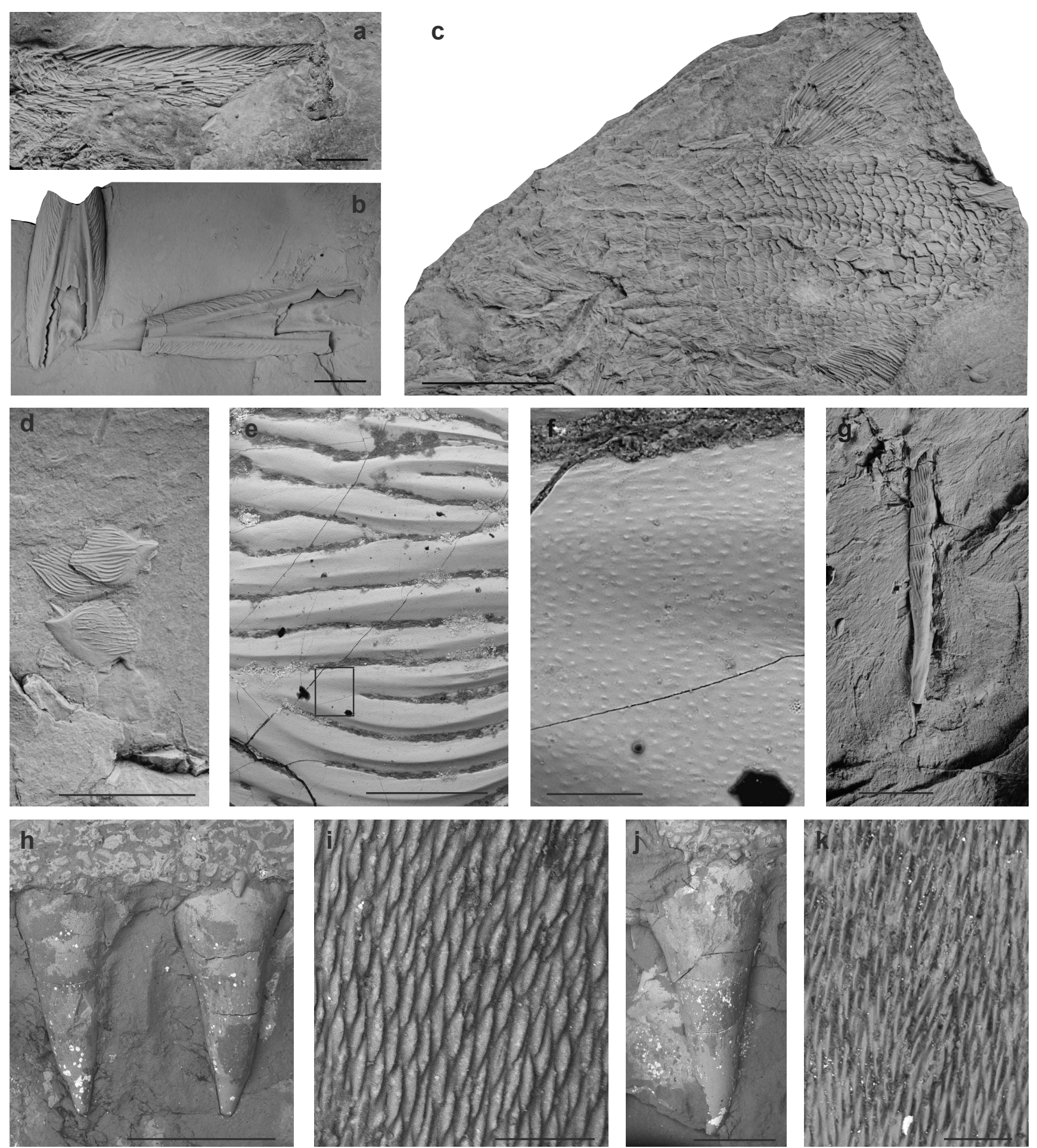

Text-fig. 10. Progyrolepis heyleri Poplin, 1999. a: dorsal lobe of the caudal fin with the fulcral scales along the dorsal edge of the lobe, GMC 55, whitened, scale bar $5 \mathrm{~mm}$; b: basal fulcral scales from the dorsal edge of the caudal peduncle, G 123, whitened, scale bar $5 \mathrm{~mm}$; c: fragment of the body of juvenile specimen with dorsal and anal fins, GMC 11, whitened, scale bar 5 mm; d: isolated scales from lateral side of the body, G 123, whitened, scale bar $5 \mathrm{~mm}$; e: ridges on the scale surface, the frame delineates the area illustrated in (f) at higher magnification, G 123, scale bar $500 \mu \mathrm{m}$; f: details of the surface with microtubercles, scale bar $50 \mu \mathrm{m}$; g: isolated lepidotrichium of an adult specimen with very short and wide segments and with unsegmented basal part, GMC 101, whitened, scale bar $5 \mathrm{~mm}$; h: large conical teeth from the internal row of the maxilla, G 123, scale bar 2 mm; i: microsculpture formed by elliptical proximo-distally elongated protuberances on the large conical tooth, G 123, scale bar $100 \mu \mathrm{m}$; j: large conical tooth from the internal row of the maxilla, G 123, scale bar $2 \mathrm{~mm}$; k: microsculpture formed by elliptical proximo-distally elongated protuberances on the large conical tooth, G 123, scale bar $100 \mu \mathrm{m}$.

The cleithrum is laterally divided into dorsal and ventral branches (GMC 130, G 123). The dorsal branch is large and triangular. It narrows conspicuously, dorsally, and ends acutely. It is 2.5 times deeper than the ventral branch which is nearly horizontal. This dorsal branch is also subdivided by a prominent ridge which separates its anterior region, 
which forms part of the branchial cavity margin, from its posterior region, exposed posteriorly to the opercular bone series during the life of the animal.

Axial skeleton. The axial skeleton is not fully preserved, in adult specimens, it is represented by arcuate ventral and dorsal elements. The ventral elements (GMC 25) are represented by dorsally forked haemal arches that continue ventrally as a pointed haemal spine (Text-fig. 8c, d). Haemal arches are highly arched and firmly integrated into the unit surrounding the haemal canal. These haemal arches and spines are very similar in shape to those of Progyrolepis heyleri (Štamberg 2018: text-fig. 21). The dorsal arcuate element ( $G$ 123) is represented by a basic neural arch element, and two slender spines, right and left, protrude from the neural arch (Textfig. 9c). It is not clear whether these arches were fused. Two slender spines, right and left, protrude from the neural arch. These spines are closely adjacent or lie together along their entire length. Some fragments are also visible; they were determined according to axial fragments also observed in Pygopterus nielseni (Aldinger 1937), Pteronisculus (Nielsen 1942) and Mimipiscis toombsi (СHоO, 2011) (Gardiner 1984). In posteroventral view, the ventral arcuate elements are V-shaped as in Pygopteus nielseni (Aldinger 1937: fig. 43) but not in Mimipiscis toombsi or Pteronisculus where they are semicircular.

The location of the ventral and dorsal arcuate elements is deduced from the description of the axial skeleton of Amia calva (Grande and Bemis 1998). According to its shape, the dorsal arch may originate from the axial skeleton in the transitional region between the abdomen and the caudal part. The tightly attached paired spines show the place on the axial skeleton where the transition between paired and median neural spines takes place. The ventral haemal arch with haemal spine probably had an initial location in the caudal region of the axial skeleton, as evidenced by the shape of the haemal arch and the opening of the haemal canal (Grande and Bemis 1998).

Fins. The pectoral fins of the juvenile specimens GMC 55 and GMC 61 consist of 17 lepidotricha. The leading pectoral fin lepidotrichium is unsegmented, with small fringed fulcra firmly connected to the anterior edge of the lepidotrichium. The following two or three lepidotrichia are not segmented in the proximal third of their length. The other lepidotrichia are articulated at their base. The dorsal fin consists of 30-35 segmented lepidotrichia (GMC 82), and the base of the dorsal fin (Text-fig. 10c) extends over 9-10 scale rows (GMC 11, GMC 82). The leading edge of the fin is protected by fulcral scales. The segments of the lepidotrichia are long and narrow because they belong to juvenile specimens (see below). The anal fin is triangular with the fulcral scales protecting the leading edge of the fin (GMC 55). The caudal fin of the juvenile specimen GMC 41 has a large ventral lobe and a relatively long dorsal lobe (1.4 times longer than the ventral lobe). These dorsal and ventral lobes form an angle of $16^{\circ}$ (GMC 55) to $20^{\circ}$ (GMC 41) with the horizontal. The dorsal edge of the dorsal lobe on GMC 55 is protected by numerous fulcral scales (Text-fig. 10a). These fulcral scales are quite upright, narrow and densely set.

The segments of the lepidotrichia are narrow and long in juvenile specimens, whereas they are very stout, wide and short in adults where they are found only isolated. Their width may be one third greater than their length. These segments also have, in their anterior half, conspicuous ridges arranged slightly obliquely across the segment of the lepidotrichium. The posterior half of the segment, in lateral view, is smooth and concave. The resulting depression allows the segment to articulate with the following lepidotrichium. The basal segment of the lepidotrichium (Text-fig. 10g) is not articulated (GMC 101). An unsegmented basal part of a lepidotrichium was also figured by Long (1988: fig. 33D) in Howqualepis rostridens. Here, the complete shape of the body is not visible. The best-preserved specimen, the juvenile GMC 11, displays most of its body with well positioned fins (Text fig. 10c). The base of the anal fin begins at the level of the dorsal fin mid-length. The tilt between the vertical scale row and the horizontal plane, just before the anal fin, is $52^{\circ}$.

On the specimens examined, the scales are scattered on the mid-lateral side and abdominal region. They are rhombic, with conspicuous peg and socket articulation and thick diagonal ridges on their external side. The longest ridge passes diagonally from the anterodorsal to the posteroventral corner of the scale, and terminates in a denticle-shaped process on the posterior margin of the scale (Text-fig. 10d). This denticle-shaped process is the third on the posterior border of the scale. The long ridge divides the lateral surface of the scale into anteroventral and posterodorsal halves. The posterodorsal ridges are short, they may join together posteriorly and protrude from the posterior edge as toothlike projections. The entire posterior edge of the scale carries tooth-like projections, $2 / 3$ of them are on the posterodorsal half of the scale. The ridges of the anteroventral half of the scale are longer, they join together and terminate in two or three tooth-like projections posteriorly. The anterior $20-25 \%$ of the surface of the scale is smooth and was covered by the preceding scales. The dorsal margin of the scales also has a smooth narrow strip. On G 123, the ridges of the scales bear a microsculpture which consists of microtubercles arranged in the same direction as the ridges (Text-fig. 10d, e, f). The base of the microtubercles is either circular or anteroposteriorly elliptical. These microtubercles are similar to those of Progyrolepis heyleri from Buxièresles-Mines (Štamberg 2018).

Some specialised scales have also been observed on GMC 55, such as a single large scale with a conspicuous ventral ridge that forms a keel lying in front of the anal fin. On G 123, isolated large basal fulcra (Text-fig. 10b) lie on the dorsal edge of the caudal peduncle. They extend in an anteroposterior direction and are 4.5 times longer than wide. Their medial part shows a deep anteroposterior groove in which the preceding basal fulcrum fits. This groove is smooth but the conspicuous ridges are visible laterally to the groove. These ridges run postertolaterally from the medial line and they anastomose.

Family Aeduellidae Romer, 1945

Genus Aeduella Westoll, 1937

Aeduella cf. blainvillei

D i a g n o s i s. See Heyler (1969) and Štamberg (2018).

Material. An operculum and a fragmentary suboperculum preserved on GMC 119. 
D e s c r i p ti o n. In lateral view, the operculum is twice deeper than long. One third of the bone bends dorsally in an anterior direction, at an angle of $153^{\circ}$. These characters are typical of Aeduella blainvillei, but there is not enough data for species determination.

\section{Permian ichthyofaunas of the French Massif Central}

The new discoveries from Brive allow a preliminary quantitative comparison between the ichthyofaunas from the French Massif Central: an estimation of individuals has been made for each Permian French basin and for each taxa or group (Tab. 1). As several specimens can belong to one individual, we preliminary estimated the minimum number of individuals: for example, several associated acanthodian spikes count for one individual (as they form several fins in a single individual), but a single isolated shark spine also counts for one individual (as it is a unique post-cephalic element). Similarly, an isolated tooth on a slab counts for one individual, but several teeth (of the same species) on the same slab also count for one individual.

Five basins of the French Massif Central yielded Permian fish; Brive, Bourbon-l'Archambault, Autun, Lodève and L'Argentière (Text-fig. 11). More precisely:

- The composition of the Brive Basin is based on the Chantepie collection described here and Heyler's notes (1969, 2008) mentioned above (see Introduction): it consists of one Sphenacanthid individual (represented by a tooth identified by SŠ), 63 Acanthodes sp., 40 Progyrolepis heyleri, one Aeduella cf. blainvillei, and 4 individuals of the endemic Briveichthys chantepieorum gen. et sp. nov. described here.

- The composition of the Bourbon-l'Archambault Basin is based on collection studies, regular excavations at Buxières-les-Mines and Franchesse (JSS 1990s and 2000s), and the literature (e.g., Heyler 1969, 1972, 1984, Heyler and Poplin 1990, Poplin 1999, Steyer et al. 2000, 2012, Schultze and Soler-Gijón 2004, Poplin and Dutheil 2005, Štamberg 2018): it consists of about 50 Xenacanthidae (sensu Beck et al. 2016), 5 Hybodontidae (cf. Lissodus; see Steyer et al. 2000), 300 Acanthodes sp., 300 Progyrolepis heyleri, 200 Aeduellidae (i.e., Aeduella sp., the endemic Bourbonnella guilloti HEYLER, 1967, and the endemic Platystella poplinae Heyler, 2002), and 20 Paramblypterus sp. (incl. Paramblypterus cf. duvernoyi).

- The composition of the Autun Basin is based on collection studies, regular excavations of the Autunian stratotype of Muse (JSS 2010s), and the literature (e.g., Heyler 1969, 1972, Poplin and Dutheil 2005, Gand et al. 2011, Gand and Steyer 2017, Luccisano et al. 2021): it consists of about 120 Xenacanthidae (incl. 20 individuals of a new endemic species of Triodus; Luccisano et al. 2021), 50 Acanthodes sp., one Dipnoi Megapleuron sp. (Gaudry 1881, Olive et al. 2012), 500 Aeduellidae (incl. Aeduella blainvillei and the endemic Platysella lallyi Heyler et Poplin, 1983), 500 Paramblypterus sp., the two latter coming from the famous "couche aux poissons" (Brignon 2014: 233) or "fish layer" from Muse.
- The composition of the Lodève Basin is based on collection studies, fieldnotes from regular excavations at La Lieude and Usclas-du-Bosc (JSS 2000s), and the literature (e.g., Heyler 1969, 1972, 1996, 2000): it consists of about 10 Xenacanthidae, 15 Acanthodes sp. and 11 Pygopteridae (incl. 4 individuals of the endemic Usclasichthys macrodens HeYLER, 1977).

- The composition of L'Argentière Basin is limited to one individual of Paramblypterus sp. found in a core of a drill (Poplin et al. 1998).

Even if these calculations are only preliminary (for example the identification of some poorly preserved specimens further than "Aeduellidae" is not possible in some basins), it is interesting to note that the Brive Basin yielded so far more fish (109 individuals in 5 groups or taxa) than that of Lodève (36 individuals in 3 groups) and L'Argentière (one individual in one group): it can therefore not be considered as a "poor" basin (Heyler 2008: 25). The richest basins in term of Permian fish are Autun $(1,171$ individuals in 5 groups) and Bourbon-l'Archambault (875 individuals in 6 groups). As all basins of the Massif Central, Brive presents a mixture of both common taxa shared with other basins (e.g., Acanthodes, Aeduellidae) and endemic taxa (e.g., Briveichthys chantepieorum gen. et sp. nov.). This confirms that all these basins were connected in time and space, probably thanks to many hydric systems (lakes, rivers etc.) which were well-developed in the tropical lower Permian climate (e.g., Poplin et al. 1998, Štamberg 2018). More precisely, the Brive Basin shares three fish taxa (Acanthodes, Progyrolepis, Aeduella) with those from Bourbon-l'Archambault and one (Pygopteridae) with those from Lodève (both Briveichthys and Usclasichthys belong to the Pygopteridae). This suggests that the Brive Basin may have acted as a passage between the North (Bourbonl'Archambault) and South (Lodève) of the Massif Central.

\section{Conclusions}

A new actinopterygian fauna from the Permian of the Brive Basin (Corrèze Département, France) is described for the first time. The new pygopterid Briveichthys chantepieorum gen. et sp. nov. is erected on the basis of a new combination of characters found on the skull roof bones, operculum and suboperculum. The parasphenoid with anterior and posterior processes is also an important feature. In this assemblage, the material is represented by disarticulated skulls, isolated bones and fragments of bodies. Most of these specimens belong to Progyrolepis heyleri according to characters found on skull roof bones, jaws, parasphenoid and opercular apparatus. Thanks to this new material, the anatomy of Progyrolepis heyleri is more accurately known, based on both juvenile and adult specimens. Additionally, an operculum and a fragmentary suboperculum were identified as belonging to Aeduella cf. blainvillei, which is relatively common in the basins of the French Massif Central. This new Brive ichthyofauna shows a close relationship with that of Buxières-les-Mines (Bourbon-l'Archambault Basin) because both share the presence of Progyrolepis heyleri, Aeduella cf. blainvillei 


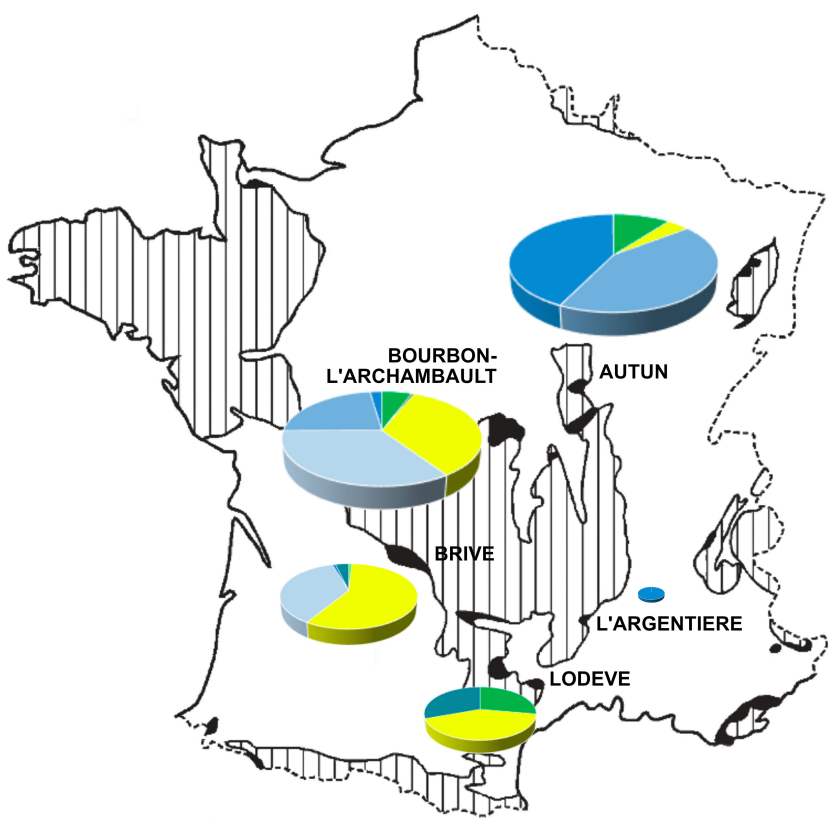

Text-fig. 11. Permian ichthyofaunas from the French Massif Central. Preliminary comparisons based on total accounts of individuals (see text for explanations). Sharks in green, Acanthodes sp. in yellow, Actinopterygians in blue, Dipnoi in white (not visible but present at Autun; see Tab. 1 for details). Each circle is proportional to the total number of specimens recovered. Permian outcrops in black. Hercynian basement indicated by vertical lines. Map modified from Gand and Durand (2006).

and Acanthodes sp. The Brive ichthyofauna also presents a degree of endemism because it contains a sphenacanthid (a single tooth) and the new pygopterid Briveichthys described here, although another pygopterid is also known in the Permian of Lodève (Usclasichthys). So far, the Brive Basin has yielded neither the Xenacanthid sharks nor the amphibians commonly found in the other basins (Bourbon1'Archambault, Autun, Lodève; e.g., Steyer et al. 2000). Given that the research on the Brive Basin fauna are only at an early stage, it can be expected that its faunistic content will be expanded during further investigation.

\section{Acknowledgements}

We sincerely thank Guy and Maryse Chantepie (Beynat) for their discoveries and their warm welcome to the Brive Basin. SŠ thanks the Erasmus Program which enabled him to study the material. JSS thanks the French Ministry of Higher Education and Research for regular credit given to the CNRS which financed the work. The authors are especially grateful to reviewers Gilles Cuny (Claude Bernard University, Lyon) and Ilja Kogan (TU Bergakademie Freiberg) for their fruitful comments and suggestions which improved the final version of the manuscript, and we would like to thank Jan Wagner and Jan Sklenář (National Museum, Prague) for careful technical preparation of the manuscript for printing.

\section{References}

Aldinger, H. (1937): Permische Ganoidfische aus Ostgrönland. - Meddelelser om Grønland, 102(3): 1-392.

Arratia, G. (2008): Actinopterygian postcranial skeleton with special reference to the diversity of fin ray elements, and the problem of identifying homologies. In: Arratia, G., Schultze, H.-P., Wilson, M. V. H. (eds), Mesozoic Fishes 4 - Homology and Phylogeny. Verlag Dr. Friedrich Pfeil, München, pp. 49-101.

Table 1. Ichthyofaunas from the Permian of the French Massif Central. Preliminary total accounts of individuals according to the taxa (lines) and basins (columns) based on the literature (see reference list), collection studies and excavations (see text for explanations). Sharks in green, Acanthodes sp. in yellow, Actinopterygians in blue, Dipnoi in white.

\begin{tabular}{|c|c|c|c|c|c|c|}
\hline TAXA / BASINS & Brive & \begin{tabular}{c|} 
Bourbon- \\
l'Archambault
\end{tabular} & Autun & Lodève & L'Argentière & TOTAL \\
\hline Chondrichthyes Sphenacanthidae & 1 & 0 & 0 & 0 & 0 & 1 \\
\hline Chondrichthyes Xenacanthidae (e.g., Orthacanthus/Bohemiacanthus, Triodus) & 0 & 50 & 120 & 10 & 0 & 180 \\
\hline Chondrichthyes Hybodontidae cf. Lissodus (in Steyer et al. 2000) & 0 & 5 & 0 & 0 & 0 & 5 \\
\hline Acanthodii Acanthodes sp. & 63 & 300 & 50 & 15 & 0 & 428 \\
\hline Actinopterygi Acrolepidae Progyrolepis heyleri & 40 & 300 & 0 & 0 & 0 & 340 \\
\hline Actinopterygi Aeduellidae (e.g., Aeduella, Bourbonella) & 1 & 200 & 500 & 0 & 0 & 701 \\
\hline Actinopterygi Amblypteridae Paramblypterus & 0 & 20 & 500 & 0 & 1 & 521 \\
\hline Actinopterygi Pygopteridae (Usclasichthys, Briveichthys) & 4 & 0 & 0 & 11 & 0 & 15 \\
\hline Dipnoi Megapleuron & 0 & 0 & 1 & 0 & 0 & 1 \\
\hline TOTAL & 109 & 875 & 1,175 & 36 & 1 & 2,192 \\
\hline
\end{tabular}

BRIVE
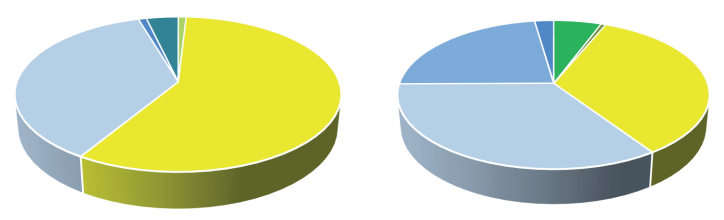

AUTUN

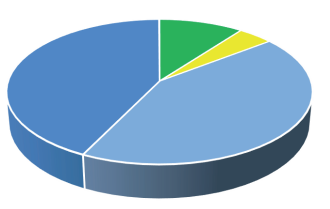

LODEVE

L'ARGENTIERE 
Beck, K. G., Soler-Gijón, R., Carlucci, J. R., Willis, R. E. (2016): Morphlogy and histology of dorsal spines of the xenacanthid shark Orthacanthus platypternus from the Lower Permian of Texas, USA: Palaeobiological and palaeoenvironmental implications. - Acta Palaeontologica Polinica, 61(1): 97-117.

Blot, J. (1966): Étude des Palaeonisciformes du Bassin de Commentry (series Cahiers de paléontologie). - Éditions du Centre national de la recherche scientifique, Paris, 99 pp.

Brignon, A. (2014): Les recherches paléoichthyologiques et géologiques sur le gisement permien de Muse près d'Autun (Saône-et-Loire) au début du XIXe siècle. - Bulletin de la Société Géologique de France, 185(4): 233-252. https://doi.org/10.2113/gssgfbull.185.4.233

Choo, B. (2011): Revision of the actinopterygians genus Mimipiscis (= Mimia) from the Upper Devonian Gogo Formation of Western Australia and the interrelationships of the early Actinopterygii. - Earth and Environmental Science Transactions of the Royal Society of Edinburgh, 102(2): 77-104. https://doi.org/10.1017/S1755691011011029

Choo, B., Long, J. A., Trinajstic, K. (2009): A new genus and species of basal actinopterygian fish from the Upper Devonian Gogo Formation of Western Australia. - Acta Zoologica, Stockholm, 90(Suppl. 1): 194-210. https://doi.org/10.1111/j.1463-6395.2008.00370.x

Cope, E. D. (1877): On the Vertebrata of the bone bed in Eastern Illinois. - Proceedings of the American Philosophical Society, 17: 52-63.

Feys, R. (1989): Le Bassin de Brive. - In: Châteauneuf, J.-J., Farjanel, G. (eds), Synthèse géologique des bassins Permiens Français. Mémoire du Bureau de recherches géologiques et minières, 128: 78-84.

Frič, A. (1875): Über die Fauna der Gaskohle der Pilsner und Rakonitzer Beckens. - Sitzungsberichte der königl. böhmischen Gesellschaft der Wissenschaften in Prag, 1875(2): 70-79.

Fritsch, A. (1895): Fauna der Gaskohle und der Kalksteine der Permformation Böhmens. Bd. III, H. 2. - F. Řivnáč, Prag, pp. 105-132.

Gand, G., Durand, M. (2006): Tetrapod footprint ichnoassociations from French Permian basins. Comparisons with other Euramerican ichnofaunas. - In: Lucas, S. G., Cassinis, G., Schneider, J. W. (eds), Non-marine Permian Biostratigraphy and Biochronology. Special Publications, Geological Society, London, 265: 157-177. https://doi.org/10.1144/GSL.SP.2006.265.01.07

Gand, G., Steyer, J. S., Chabard, D. (2011): Reprise de fouilles paléontologiques dans un gîte bourguignon célèbre: les « schistes bitumineux » de l'Autunien de Muse (Bassin d'Autun) - Bilan 2010 et perspectives. - Revue scientifique Bourgogne-Nature, 12: 10-29.

Gand G., Steyer, J. S., Kubiak, J., Chaussard, P., Lacour, J. (2017): Comptes-rendus d'activités 2015-17 et projets de recherches dans le stratotype Autunien et le Rhétien du Plateau d'Antully. - Bulletin de la Société d'Histoire naturelle d'Autun, 211: 6-18.

Gardiner, B. G. (1984): The relationships of the palaeoniscoid fishes, a review based on new specimens of Mimia and Moythomasia from the Upper Devonian of
Western Australia. - Bulletin of British Museum (Natural History), Geology series, 3(4): 173-428.

Gaudry, A. (1881): Sur un nouveau genre de poisson primaire. - Comptes rendus hebdomadaires des séances de l'Académie des sciences, Paris, 92: 752-754.

Giebel, C. G. (1848): Fauna der Vorwelt mit steter Berücksichtigung der lebenden Thiere. Erter Band: Wirbelthiere. Dritte Abteilung: Fische. - F. A. Brockhaus, Lepzig, 467 pp. https://doi.org/10.5962/bhl.title.24938

Grande, L., Bemis, W. (1998): A comprehensive phylogenetic study of amiid fishes (Amiidae) based on comparative skeletal anatomy. An empirical search for interconnected patterns of natural history. - Memoir, Society of Vertebrate Paleontology, 4: 1-690. (Supplement to Journal of Vertebrate Paleontology, vol. 18, no. 1) https://doi.org/10.1080/02724634.1998.10011114

Heyler, D. (1967): Quelques points nouveaux au sujet d'Aeduella Westoll. - Colloques internationaux du Centre national de la recherche scientifique, 163: 81-88.

Heyler, D. (1969): Vertébrés de l'Autunien de France (series Cahiers de Paléontologie). - Éditions du Centre national de la recherche scientifique, Paris, 312 pp.

Heyler, D. (1972): Aeduelliformes (Actinoptérygiens de l'Autunien du Massif Central). - Revue scientifique du Bourbonnais, 72: 68-83

Heyler, D. (1977): Découvertes ichthyologiques dans le Permien de Lodève; une nouvelle structure dentaire. - Géologie mediterranéenne, 4(3): 189-204. https://doi.org/10.3406/geolm.1977.1001

Heyler, D. (1984): Faune fossile du Permien de l'Allier. Revue scientifique du Bourbonnais, 84: 103-122.

Heyler, D. (1996): Les vertébrés permiens du bassin de Lodève (Hérault): bilan. - Bulletin de la Société d'Histoire naturelle d'Autun, 157: 5-28.

Heyler, D. (2000): Les actinoptérygiens stéphaniens et autuniens du Massif Central (France) dans les collections du MNHN (Paris) et du Musum d'Autun: compléments, mises au point, bilan. - Bulletin de la Société d'Histoire naturelle d'Autun, 169: 7-44.

Heyler, D. (2002): Inventaire des Vertébrés de l'Autunien de Bourbon-l'Archambault (Allier) dans les collections du MNHN (Laboratoire de Paléontologie) et un nouveau Platysella. - Revue scientifique du Bourbonnais, 2002: 17-40.

Heyler, D. (2008): Vertébrés du Stéphanien de Saint-Étienne dans les collections du MNHN. - Bulletin de la Société d'Histoire naturelle d'Autun, 196: 25-40.

Heyler, D., Poplin, C. (1983): Actinopterygiens du Stéphanien de Montceau-les-Mines (Saône-et-Loire, France). Palaeovertebrata, 13: 33-50.

Heyler, D., Poplin, C. (1990): Les Vertébrés autuniens de Buxières-les-Mines (Allier, France). - Bulletin du Muséum national d'Histoire naturelle, Paris, 12(4): 225-239.

Kazanceva-Selezneva, A. A. (1977): K sisteme i filogenii otryada Palaeonisciformes [System and Phylogeny of the Order Palaeonisciformes]. - In: Ocherki po filogenii i sistematike iskopaemykh ryb i bezchelyustnykh [Studies in the Phylogeny and Systematics of Fossil Agnathans and Fishes]. Nauka, Moscow, pp. 98-116. (in Russian) 
Long, J. A. (1988): New palaeoniscoid fishes from the Late Devonian and Early Carboniferous of Victoria. - Memoires of the Association of Australian Paleontologists, 7: 1-64.

Luccisano, V., Pradel, A., Amiot, R., Gand, G., Steyer, J. S., Cuny, G. (2021): A new Triodus shark species (Xenacanthidae, Xenacanthiformes) from the lowermost Permian of France and its paleobiogeographic implications. - Journal of Vertebrate Paleontology, 41(2): e1926470 (18 pp.). https://doi.org/10.1080/02724634.2021.1926470

Nielsen, E. (1942): Studies on Triassic fishes from East Greenland. I. Glaucolepis and Boreosomus. - Meddelelser om Grønland, 138: 1-403.

Olive, S., Clément, G., Pouillon, J.-M. (2012): First occurrence of the lungfish Sagenodus (Dipnoi, Sarcopterygii) from the Carboniferous Lagerstätte of Montceau-les-Mines, France. - Journal of Vertebrate Paleontology, 32(2): 285-295. https://doi.org/10.1080/02724634.2012.646799

Pellenard, P., Gand, G., Schmitz, M., Galtier, J., Broutin, B., Stéyer, J. S. (2017): High-precision U-Pb zircon ages for explosive volcanism calibrating the NW European continental Autunian stratotype. - Gondwana Research, 51: 118-136. https://doi.org/10.1016/j.gr.2017.07.014

Poplin, C. (1999): Un paléoniscoïde (Pisces, Actinopterygii) de Buxières-les-Mines, témoin des affinités fauniques entre Massif central et Bohême au passage Carbonifère-Permien. - Geodiversitas, 21(2): 147-155.

Poplin, C., Dutheil, D. B. (2005): Les Aeduellidae (Pisces, Actinopterygii) carbonifères et permiens: systématique et étude phylogénétique préliminaire. - Geodiversitas, 27(1): 17-33.

Poplin, C., Farjanel, G., Genna, A., Razin, P. (1998): Présence d'un paléoniscoïde (Pisces, Actinopterygii) dans l'Autunien de Morte-Merie (Ardêche, France); sédimentologie, biostratigraphie, paléoenvironnement. - Bulletin de la Société Géologique de France, 169(3): 343-349.

Poplin, C., Véran, M. (1996): A revision of the actinopterygian fish Coccocephalus wildi from the Upper Carboniferous of Lancashire. - In: Milner, A. R. (ed.), Studies on Carboniferous and Permian vertebrates. Special Papers in Paleontology, 52: 7-29.

Poschman, M., Schindler, T. (2004): Sitters and Grügelborn, two important Fossil-Lagerstaetten in the Rotliegend (?Late Carboniferous - Early Permian) of the Saar-Nahe Basin (SW-Germany), with the description of a new palaeoniscoid (Osteichthyes, Actinopterygii). - In: Schoch, R. R., Müller, J., Fastnacht, M. (eds), Studies in lower vertebrate palaeontology in honour of Jürgen Boy. Neues Jahrbuch für Geologie und Paläontologie, Abhandlungen, 232(2-3): 283-314. https://doi.org/10.1127/njgpa/232/2004/283

Romer, A. S. (1945): Vertebrate Paleontology ( $2^{\text {nd }}$ ed.). University of Chicago Press, Chicago, 687 pp.

Richter, M. (1983): Ultra-estrutura de dentes de Paleoniscídeos (Pisces) do Grupo Passa Dois, RS, Brasil [Ultrastructure of the teeth of palaeoniscoids (Fishes) of the Group Passa Dois, RS, Brazil]. - Iheringia, Sér. Geologia, 8: 131-145. (in Portuguese)

Sauvage, H.E. (1888): Poissons du terrain Houiller de Commentry. - In: Études sur le terrain Houiller de Commentry, Livre
3 - Faunes ichthyologique et entomologique, pt. 1. Société de l'Industrie Minérale, St-Etienne, pp. 39-120.

Schindler, T. (1993): “Elonichthys" palatinus n. sp. a new species of actinopterygians from the Lower Permian of the Saar-Nahe Basin (SW-Germany), with the description of a new palaeoniscoid (Osteichthyes, Actinopterygii). - In: Heidtke, U. (ed.), New Research on PermoCarboniferous Faunas. Pollichia-Buch, 29: 67-81.

Schindler, T. (2018): Neubeschreibung und erste Rekonstruktion von Elonichthys germari Giebel, 1848 (Pisces, Actinopterygii; Oberkarbon, Mitteldeutschland). - Hallesches Jahrbuch für Geowissenschaften, 41: 1-33.

Schultze, H.-P., Soler-Gijón, R. (2004): A xenacanthus clasper from the uppermost Carboniferous-Lower Permian of Buxières-les-Mines (Massif Central, France) and the palaeoecology of the European Permo-Carboniferous basins. - In: Schoch, R. R., Müller, J., Fastnacht, M. (eds), Studies in lower vertebrate palaeontology in honour of Jürgen Boy. Neues Jahrbuch für Geologie und Paläontologie, Abhandlungen, 232(2-3): 325-363. https://doi.org/10.1127/njgpa/232/2004/325

Stensiö, E. A. (1921): Triassic fishes from Spitzbergen, Part 1. - A. Holzhausen, Vienna, 307 pp., 35 pls. https://doi.org/10.5962/bhl.title.159141

Steyer, J. S., Escuillié, F., Pouillon, J. M., Broutin, J., Debriette, P., Freyet, P., Gand, G., Poplin, C., Rage, J. C., Rival, J., Schneider, J. W., Štamberg, S., Werneburg, R., Cuny, G. (2000): New data on the flora and fauna from the ?uppermost Carboniferous-Lower Permian of $\mathrm{Bu}$ xières-les-Mines, Bourbon l'Archambault Basin (Allier, France). A preliminary report. - Bulletin de la Société Géologique de France, 171(2): 239-249. https://doi.org/10.2113/171.2.239

Steyer, J. S., Sanchez, S., Debriette, P., Valli, A. M. F., Escuillié, F., Pohl, B., Dechambre, R.-P., Vacant, R., Spence, C., de Ploëg, G. (2012): A new vertebrate Lagerstätte from the Lower Permian of France (Franchesse, Massif Central): palaeoenvironnemental implications for the Bourbon-l'Archambault basin. - Bulletin de la Société Géologique de France, 183(6): 509-515. https://doi.org/10.2113/gssgfbull.183.6.509

Stamberg, S. (1991): Actinopterygians of the Central Bohemian Carboniferous Basins. - Acta Musei Nationalis Pragae, Series B - Historia Naturalis, 47(1-4): 25-104.

Štamberg, S. (2007): Permo-Carboniferous Actinopterygians of the Boskovice Graben. Part 1. Neslovicella, Bourbonnella, Letovichthys, Elonichthys. - Museum of Eastern Bohemia, Hradec Králové, 155 pp.

Štamberg, S. (2010): Taxonomic remarks on Rhabdolepis saarbrueckensis Gardiner, 1963 (Osteichthyes: Actinopterygii) and its relationships to some actinopterygians from the Late Carboniferous of the Bohemian Massif, Czech Republic. - Journal of the National Museum (Prague), Natural History Series, 179(15): 153-170.

Štamberg, S. (2018): Actinopterygians of the Permian locality Buxières-les-Mines (Bourbon-L'Archambault Basin, France) and their relationship to other early Actinopterygians. - Fossil Imprint, 74(3-4): 245-291. https://doi.org/10.2478/if-2018-0017

Watson, D. M. S. (1925): The structure of certain paleoniscids and the relationships of that group with other bony 
fish. - Proceeding of the Zoological Society of London, 1925: 815-870.

https://doi.org/10.1111/j.1469-7998.1925.tb07107.x

Westoll, T. S. (1937): On a remarkable fish from the Lower Permian of Autun, France. - The Annals and Magazine of Natural History, Ser. 10, 19: 553-557.

https://doi.org/10.1080/00222933708655302
Westoll, S. T. (1944): The Haplolepidae, a new family of Late Carboniferous bony fishes. - Bulletin of the American Museum of Natural History, 83(1): 1-121.

Woodward, A. S. (1906): On a carboniferous Fish Fauna from the Mansfield District, Victoria. - Memoirs of the National Museum, Melbourne, 1906(1): 1-32. https://doi.org/10.24199/j.mmv.1906.1.01 